\title{
Agriculture and Rural Development
}

\section{Ministries' Level}

\section{Strategy Development Workshop}

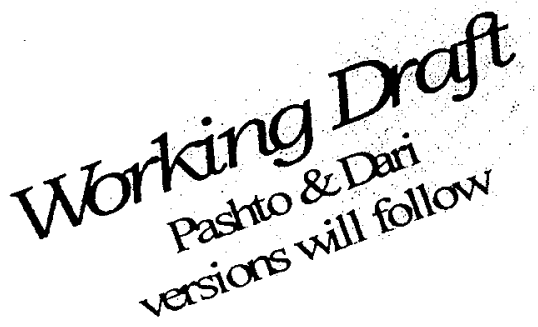

$28^{\text {th }}$ Sept. $-2^{\text {nd }}$ Oct., 2003

Kabul

Facilitation \& Report by

Mahmood Hemani

For copies, comments, feedback, and queries please contact

FAO Program Management Unit, either of following

Mr. Manfred Staab, Programme Manager

manfred.staab@af.fao.org Ph: 070 - 288165

$\mathrm{Mr}$. Abdul Rahim, Senior National Programme Officer

abdul.rahim@af.fao.org Ph:070-299033

Jointly Organised by

UNITED NATIONS FOOD \& AGRICULTURE ORGANIZATION (UN FAO Afghanistan Programme)

Ministry of Agriculture and Animal Husbandry

Ministry of Irrigation, Water Resources and Environment

Ministry of Rural Rehabilitation and Development

Government of Afghanistan 

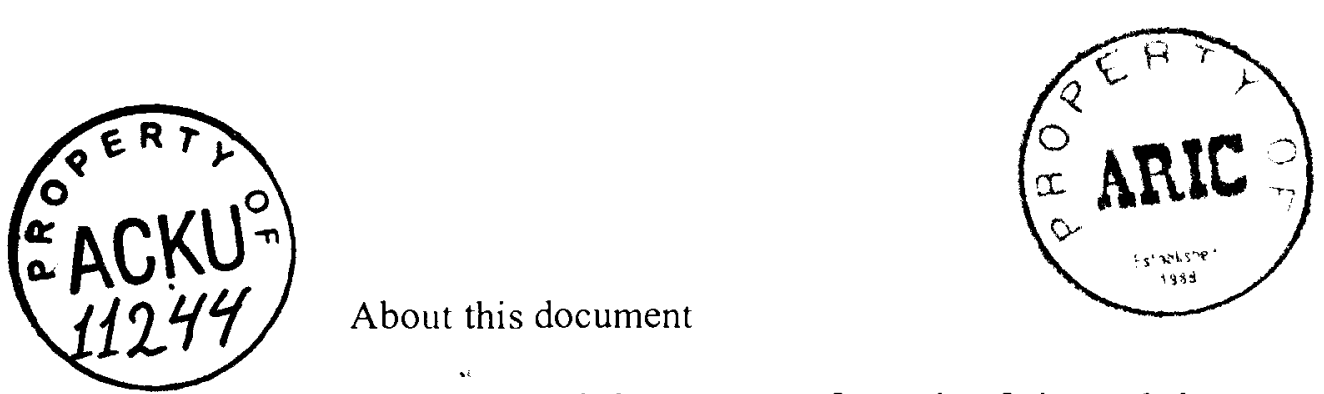

This document presents the outcome of one work undertaken in all regions of Afghanistan (Kandahar, Herat, Mazar, Jalalabad, Kabul (2x) with approximately 350 participants in total. With a few exceptions a!l of the participants were experienced Afghan professionals and officers of the Government.

The workshops took place between July and September 2003 and were jointly organized and implemented by the area offices of FAO and the provincial departments of FAO's partner agencies (MAAH, MIWRE, MRRD) in the regions. Considering the reality in the rural areas of the country the workshops aimed to look at agriculture in the context of rural development and livelihood.

The documents of all six workshops will be printed in English, Dari and Pashto and distributed to all participants of the workshops. A sufficient number will go to the provincial departments, to the Ministries on central level and any other interested party.

At this point in time the workshop documents, together with a number of strategic papers developed by different persons and groups (including FAO's "Strategy on early rehabilitation of the agricultural sector in Afghanistan", 2002) present one of the most comprehensive collection of data and information inputs for strategic and operational development.

The workshop methodology applied is based on a strictly participatory approach combining training elements with elements of practical planning. Therefore this document contains a fruitful mixture of method and results. Most of the results discussed and agreed upon in the workshops (see chapter 12 "Strategy Planning") can be used further to develop an overall strategy for agriculture and rural development in Afghanistan, or for other sectoral planning exercises.

The process developed and the results achieved can also be utilized in a new phase or follow up of the TAPA system.

The planning issues discussed by the participants - and forwarded in this document to interested parties in Afghanistan and the international communities - do form a solid basis for conceptualization and design of projects and preparation of project proposals

Comments, suggestions, reflections are very much appreciated.

Kabul. ()cober 2003-10-14

Manfied Silab

FAO Programme Manager

manfred staabadfao org
Abdul Rahim

fis) Senior National Programme (officer

abdut rahimarafao ory 


\section{Table of Contents}

$\begin{array}{rlr}1 . & \text { List of Abbreviations } & 3 \\ 2 . & \text { Acknowledgement } & 4 \\ 3 . & \text { Background } & 5 \\ 4 . & \text { Introduction } & 6 \\ 5 . & \text { Workshop Inauguration } & 7 \\ 6 . & \text { Role of State } & 9 \\ 7 . & \text { Introduction to Workshop Methodology \& Participants } & 10 \\ 8 . & \text { Planning Framework } & 11 \\ 9 . & \text { Problem Analysis } & 12 \\ 10 . & \text { Objective Analysis } & 26 \\ 11 . & \text { Stake-holder Analysis } & 40 \\ 12 . & \text { Strategy Planning } & 50 \\ 13 . & \text { Workshop Evaluation } & 55 \\ 14 . & \text { Workshop Closing \& Adjournment } & 59\end{array}$

\section{Annexes}

\#1 Complete list of participants

\#2 Workshop Photos 


\section{List of Abbreviations}

$\begin{array}{ll}\text { BOT } & \text { Build, Operate and Transfer } \\ \text { FAO } & \text { Food \& Agriculture Organization } \\ \text { iNGOs } & \text { International Non-Governmental Organizations } \\ \text { IOM } & \text { International Organisation for Migration } \\ \text { M+E } & \text { Monitoring and Evaluation } \\ \text { MAAH } & \text { Ministry of Agriculture and Animal Husbandry } \\ \text { MIWRE } & \text { Ministry of Irrigation, Water Resources and Environment } \\ \text { MRRD } & \text { Ministry of Rural Rehabilitation and Development } \\ \text { NGOs } & \text { Non-Governmental Organisation } \\ \text { PPM } & \text { Project Planning Matrix } \\ \text { TORs } & \text { Terms of Reference } \\ \text { UN } & \text { United Nations } \\ \text { UNDCP } & \text { United Nations International Drug Control Programme } \\ \text { UNHCR } & \text { United Nations High Commission for Refugees } \\ \text { UNICEF } & \text { United Nations Children Fund } \\ \text { UNOCHA } & \text { United Nations Office of Coordinator for Humanitarian Assistance to } \\ & \text { Afghanistan } \\ \text { UNOPS } & \text { United Nations Office for Project Services } \\ \text { WHO } & \text { World Health Organisation } \\ \text { ZOPP } & \text { "Ziel Orientierte Projekt Plannung" (Objectives Oriented Project Planning }\end{array}$




\section{Acknowledgement}

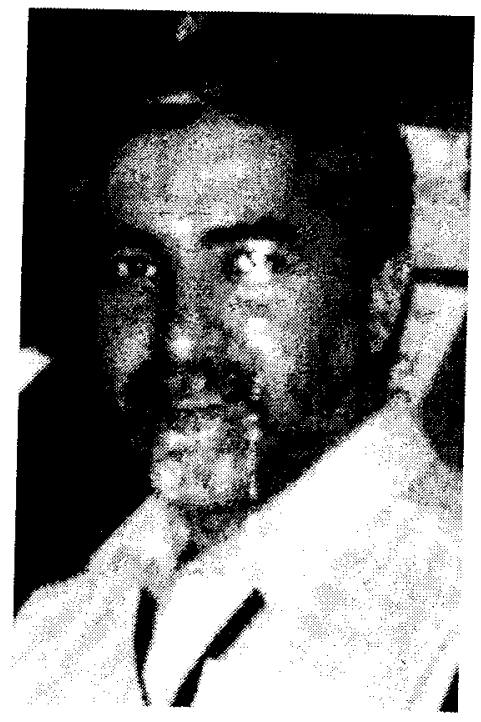

I would like to take this opportunity to thank all the participants for their active and valuable participation and their co-operation which made the workshop a success.

I am thankfult to Engr. Abdul Rahim, Mr. Waheed Rahimi and Mr. Gul Jacha for the transl ttion support, witho it which it would ha:e been difficult to conduct the workshop.

Of course, not to forget Ms. Lina Sehatmand and her team for admirably handling the organizational matters.

Last but not least, I am thankful for the valuable assistance provided by the FAO Programme Office in Kabul for the workshops, in particular, the guidance and insight about the objectives by Mr. Manfred Hans Staab, and for logistic and organizational support by Mr. Abdul Rahim and Mr. Waheed Rahimi.

Mahmood Hemani

ViCAR Consult

vicar@cyber.net.pk 


\section{Afghanistan's Projected Total Population 2003 On the basis of UNIDATA 1990 Population Estimates}

\begin{tabular}{|c|c|c|c|c|}
\hline $\begin{array}{l}\text { Province } \\
\text { N:me }\end{array}$ & District Code & $\begin{array}{l}\text { Number of } \\
\text { Villages }\end{array}$ & Area (KM2) & Projected Population 2003 \\
\hline Kabul & 100 & 337 & 4,720 & $2,851,086$ \\
\hline Kapisa & 200 & 479 & 5,404 & 587,747 \\
\hline Parwan & 300 & 372 & 5,960 & 696,084 \\
\hline Wardak & 400 & 687 & 9,699 & 499,434 \\
\hline Logar & 500 & 272 & 4,409 & 367,671 \\
\hline Bamyan & $\underline{2800}$ & $\underline{277}$ & $\underline{17,546}$ & 456,424 \\
\hline Paktya & 700 & 626 & 5,577 & 520,021 \\
\hline Ghazni & 600 & 1,508 & 21,381 & $1,071,699$ \\
\hline Khost & 700 & 610 & 4,201 & 354,327 \\
\hline Paktika & 2900 & 648 & 19,409 & 415,988 \\
\hline Nangarhar & 800 & 494 & 7,607 & $1,268,027$ \\
\hline Kunar & 1000 & 356 & 10,552 & 425,172 \\
\hline Laghman & 900 & 332 & 7,227 & 528,214 \\
\hline Badakhshan & 1100 & 657 & 40,886 & 845,520 \\
\hline Takhar & 1200 & 781 & 12,325 & 886,866 \\
\hline Samangan & 1500 & 419 & 16,640 & 463,339 \\
\hline Kunduz & 1400 & 392 & 7,928 & 944,133 \\
\hline Balkh & 1600 & 426 & 12,284 & 967,620 \\
\hline Saripul & 1700 & 296 & 16,530 & 551,633 \\
\hline Jawzjan & 1700 & 351 & 14,276 & 649,126 \\
\hline Faryab & 1800 & 601 & $.16,727$ & 791,615 \\
\hline Baghlan & 1300 & 390 & 17,165 & 839,516 \\
\hline Kandahar & 2400 & 835 & 49,372 & 977,306 \\
\hline Helmand & 2300 & 838 & 62,337 & 879,894 \\
\hline Nimroz & 2200 & 458 & 41,724 & 176,158 \\
\hline Oruzgan & 2600 & 401 & 28,929 & 741,822 \\
\hline Zabul & 2500 & 830 & 17,068 & 304,879 \\
\hline Heart & 2000 & 1,102 & 38,799 & $1,149,780$ \\
\hline Ghor & 2700 & 867 & 38,758 & 574,537 \\
\hline Badghis & 1900 & 336 & 21,678 & 397,096 \\
\hline Farah & 2100 & 552 & 59,147 & 556,353 \\
\hline \multicolumn{2}{|c|}{ Total } & 17530 & 636,265 & \\
\hline
\end{tabular}




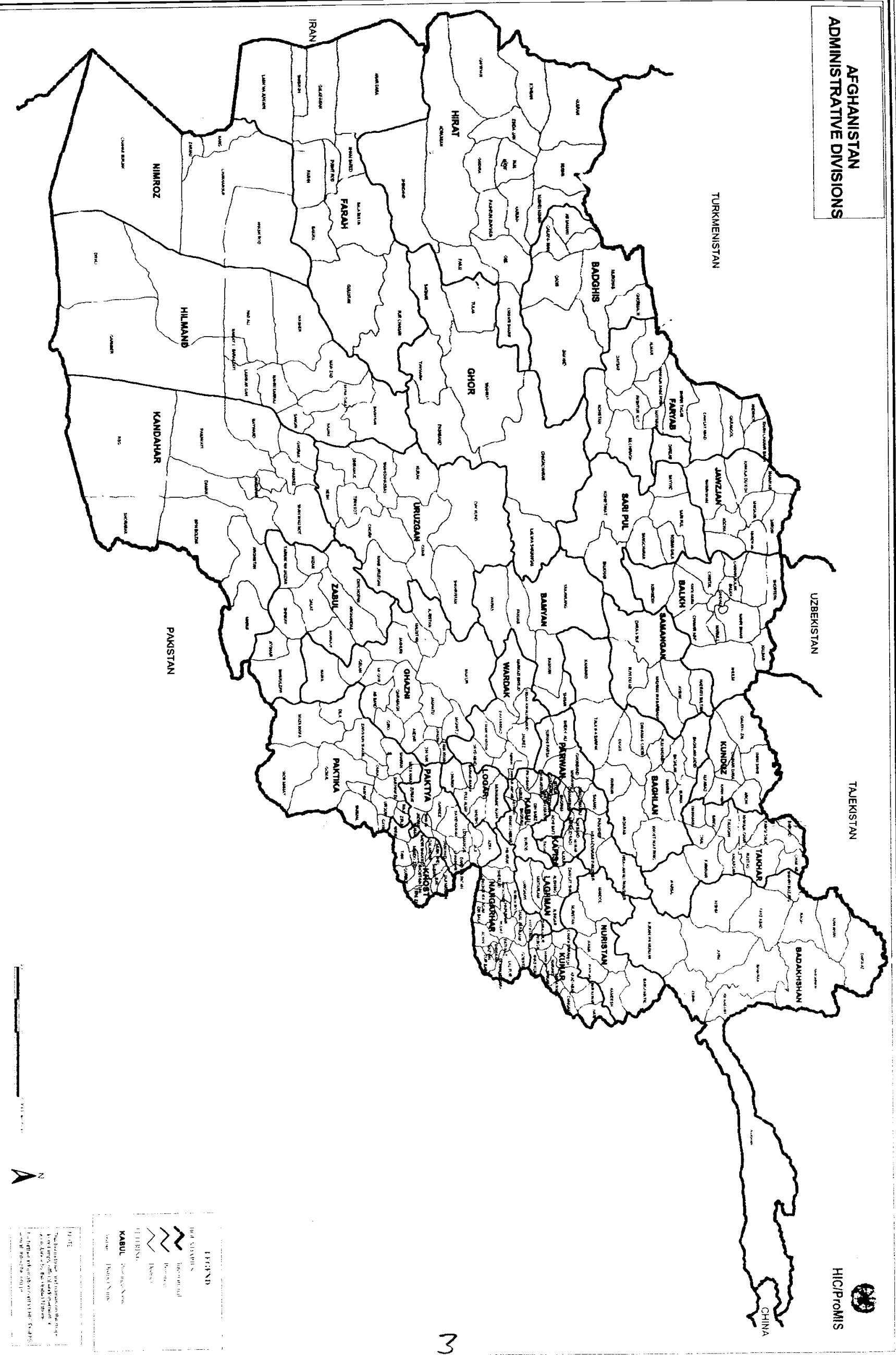




\section{Background}

Afghanistan is a land lock country consisting of high mountains and steep valleys in the north-east and central parts and wide plains in west and south west. The central mountains receive the highest amount of precipitation, particularly ir the winter and spring seasons. Precipitation run-off from the mountains reaches the rest of the country, creating seasonal and permanent rivers. The past several years of drought have badly affected irrigation, severely damaging the country's agricultural sector, and putting millions people in danger. Some $80-85 \%$ of Afghanistan's economy is dependant on agriculture. About $12 \%$ of the total land area is arable, around $2 \%$ is under forest cover, $46 \%$ is permanent pastures and the rest is mountainous or desert.

Afghanistan's 9,000 meter high mountains, its steep valleys and wide deserts in the north, west, and south west, produce heterogeneous climatic conditions. The center of the country is arid, the west semi-arid, the south semi-humid with the south east containing semi-arid and semi-humid regions, and humid in north-east parts of the country. Elevation ranges from 200 meters to 9.000 meters, permitting four different seasons per year. While there is no exact population figure for Afghanistan, UNIDATA estimates the country's population at 23 million in 2003. Out of this, about 10 million people live in rural areas and about 1.5 million are nomads (Kuchis). The country is comprised of 32 provinces and 337 districts. The district is the smallest administrative unit of the country. Since 1992, many new districts have been created. However, exact figures on their size, borders, and population are still not available.

Wheat is Afghanistan's staple crop, accounting for about $70 \%$ of total cereal consumption and about $30 \%$ of the agriculture production. Other important crops include rice, maize, millet, barley and pulses. Potatoes, onions and several fruit crops including melons, watermelons, apricot, pomegranates and grapes are produced for domestic consumption and export. Most families grow vegetables for home consumption. At least $6 \%$ of the total irrigated area is planted with vegetables. Okra, tomatoes and onions are widely grown, especially in central, eastern and northeastern provinces.

Cotton was an important industry in the 1970s, with a production area of around 170,000 hectares. According to the 1997 FAO survey of the sector, this had shrunk to 112,000 hectares by the end of 1990s. Processing facilities were located in Herat, Kandahar and Kunduz provinces, but by 1997, not much cotton was processed inside the country. Cotton planting has declined to the level of cottage industry in northern parts of the country. Poppy is a traditional crop in some parts of Afghanistan, but due to the war and drought, some farmers in non-traditional areas are now cultivating poppies as a cash crop. Limited quantities of cannabis are grown, mainly for personal and medicinal use.

Pre-war, state-run extension services were centralised and top heavy. The Ministry of Agriculture and Animal Husbandry employed thousands of extension workers and huge state farms were set up. There was a national network of agricultural educational services provided by technical colleges and university faculties. Now almost all services are provided by NGOS and UN agencies. In the 1960s and 1970s exports of high value horticultural products provided Afghanistan with $48 \%$ of its export revenue. Prior to the Soviet invasion of 1979 Afghan annual exports averaged around US\$600 million, of which $30 \%$ was dried and $7 \%$ was fresh fruits. Afghanistan was the world leader in raisin 
production in the 1960s, producing high value 'shindukhani' and 'kishmishi' varieties. Today most of the vineyards have been destroyed by war or drought.

A combination of war, exploitation, population pressure and mismanagement has degraded Afghanistan's natural resources, especially forests and rangeland. Drought is often cited as the main cause for this degradation but it has been the breakdcwn of traditional management strategies that has led to widespread non-sustainable resource use across the country. Once, $2 \%$ Afghanistan was covered with forests. Deforestation is extensive because of widespread timber smuggling, especially to Pakistan, and unregulated felling of trees, including fruit trees, for fuel wood. Remaining forests are situated between 1,500 meters and 3,600 meters above sea level in the north, east and southeast of the country. The main forest species are ash, cedar, juniper, oak, olive, pine, spruce fir and willow. Wood is mainly used for fuel and construction.

Livestock is integral to Afghanistan's economy and culture. Animals provide farm draught power, nutrition, raw materials for goods and tradable products. Cattle, sheep and goats are the country's most important livestock, though camels, asses, water buffalo and yaks are as known and used throughout the country. Poultry is also an important source of nutrition and income. In Afghanistan, there are two major systems of animal husbandry: sedentary, practiced by farmers who raise both animals and crops; and nomadic, practiced by Kuchis. In many areas, management and rearing of sheep and goats are the responsibility of women.

Access to water is at the heart of Afghanistan's evolution to a peaceful and stable nation. Lack of water as a result of drought, mismanagement and negligible infrastructure has contributed to massive population displacement, increased opium production, conflicts over land and grazing, and community ill-health. Afghanistan has enough water to satisfy current needs. The average annual available surface water in Afghanistan is estimated at 84,000 million m3. However, most of this runs off to neighboring countries, from the Panj River to Tajikistan, from the Kabul River to Pakistan, from the Helmand and Harirud rivers to Iran, from the Amu River to Turkmenistan and Uzbekistan, and from the Murghab River to Turkmenistan. With proper management, some 57,000 million m3 of surface water would be available to Afghanistan per year, about 2,500 m3 per person.

The potential irrigable area in Afghanistan has been estimated at 5 million hectares. FAO estimates for 1978 indicate an irrigated area of 2.65 million hectares, with 1.4 million having sufficient water for double cropping. Most irrigation systems are traditional and $55 \%$ of total irrigated area using informal river diversion structures. Others are traditional systems based on springs, seasonal streams, karee or arhad. The traditional irrigation systems are grouped into surface and karez systems. The management of these systems is based on ancient customs that include the division of water, shared responsibilities for repair and maintenance and the settlement of disputes. Formal irrigation systems cover only $15 \%$ of total irrigated area. These are state-owned systems which were engineered between the 1950s and 1970s with the financial and technical assistance of the USSR and the USA. Most of them no longer work effectively as a result of drought and neglect. 


\section{INTRODUCTION}

This report covers the proceedings and results of a five-day workshop held in Kabul from $28^{\text {th }}$ September to $2^{\text {nd }}$ October, 2003 to prepare an overall strategy for the Agriculture sector and (allied) Rural Development in the Northern region of Afghanistan. This workshop concentrated on the joint strategy by the three ministries - Ministry of Agriculture \& Animal Husbandry (MAAH), Ministry of Irrigation, Water Resource and Environment (MIWRE) and Ministry of Rural Rehabilitatior and Development.

The methodology used in the workshop is based on ZOPP - an acronym for the German term "Ziel Orientierte Projekt Plannung" (Objectives Oriented Project Planning). ZOPP is participatory planning methodology that uses a sequence of successive steps leading to a planning matrix which illustrates the basic structure of the overall programme/project. However, due to the very nature of the event, the workshop did not attempt to workout indicators and assumptions.

Also, for this workshop, the format was different from those of the regional level strategy planning workshops. This change was made with the view to sensitize the group of the different nature of responsibilities the ministries have compared to the provincial departments. Thus, efforts were made to enhance the understanding as "Sector Manager" then that of an "implementer". Chiefly, the difference was that separate groups (analysis) were not created for the forest and livestock sub-sectors of the agriculture. Instead an additional element of "Private Sector" participation in development - especially in provision of services was attempted.

The attendees were the Directors, technical and administrative staff from the three ministries; and, representatives of local and international NGOs - AREA, ACTED, OXFAM, ICARDA, SCA, ISRA, CHA and NPO. The Deputy Ministers of MAAH and MRRD inaugurated the workshop. A complete list of workshop participants is presented in annex \#1.

The workshop was conducted in a fashion that simultaneous English to Pashto/Dari and vice versa translations were done to ensure full participation of all. This process, though it took time, greatly helped the participants to discuss and express their opinion in their native language thereby avoiding any misunderstanding due to language constraints. To facilitate the translation business, workshop utilised the expertise of two translators who not only did translations but also greatly helped in getting the messages across.

The workshop succeeded in achieving the objectives assigned to it. On pure technical grounds, the analyses and strategy may s till be deficient and c an certainly be improved; however, the uniqueness of the products is that these are the heart-felt priorities of the people / staff engaged at national level. Thus, the distinctive value of workshop outcomes deserves its due importance to be realized.

Additionally, for the participants, the workshop provided a rare opportunity to such a diverse, yet closely allied professional groups to collectively contemplate the existing situation and the future direction. Also, a unique exposure to planning technique, teamwork, broad thinking and taskoriented participation has resulted in full ownership of the "strategy".

The Afghans are known for their determination and hard works, however, the turbulences of a quarter of century have made this country extremely resource starved. Thus, it cannot, on its own re-build itself and it is now the responsibility of the aid community to help realize the strategy.

It would be beneficial for the interim Afghan Government to integrate the strategy - prepared by Afghans themselves, into the overall development agenda and start initiation of the "resourceneutral" tasks. This, on one hand would enhance the confidence of the people in the strategy, while, on the other, it would signal the donors that the prerequisites are being done and may facilitate in early partnership agreement(s). 
The workshop started with the recitation of few verses from the Holy Quran.

Engr. Abdul Rahim, Senior National Programme Officer welcomed the participants from the ministries and NGOs to the workshop and briefly narrated the objectives of the workshop.

Inaug ırating the workstop, Engr. Sharif, Deputy Minister (MAAH) expressed his delight to open the workshop m eant for, much n eeded, development of capacities and policy (strateyy) planning for agriculture and rural development. He stated that the country is slowly moving towards development and food situation is improving with the help of $\mathrm{FAO}$ and others. He stressed that the three ministries have to work together to meet all the needs of the people. For the improvement of all sectors, he stressed, the planning is very important. It contributes in mental development of the staff and that the follow up of the workshop results would be must. Apprising the workshop, Engr. Sharif mentioned

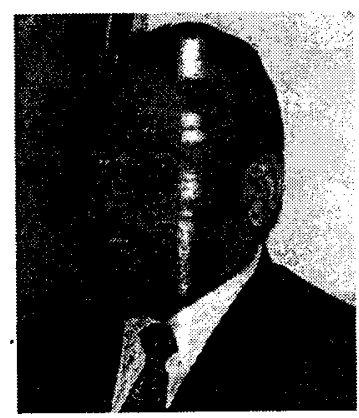
that Centre (national government) does not want to dictate thus a bottom up approach is a must and requested that planning at village level should be given equal importance.

Speaking about the current situation, the Engr. Sharif pointed out that on one hand the displaced people are coming back while all systems are damaged. Not even the basic (agricultural) tools are available, despite that people are trying to cope with the situation. He stated that indigenous knowledge should be given its due value and utilized, as locals know many solutions, e.g. sources of water in their own areas. Also, it was stressed that we must identify the people who made improvements by themselves in various field and must polish them to play their role in the development process. However, it is equally necessary to introduce new knowledge and skills to conserve the soil fertility and natural resources. Thus, "policy making should benefit from peoples knowledge - in fact, people are the real policy makers".

Though the last three seasons have shown better results but keeping in view the problems faced by the farmers especially with regard to seeds, the deputy minister, urged that code of conduct for seed (production/multiplication and sale) is a must to maintain the quality levels; as the qualitative aspect of rural development calls for "low input - high quality + quantity".

Though the NGOs and UN have done good job over the years but collective planning and strategy with transparency of works and funds is a must. This is also necessary to avoid the duplication and concentration of interventions in specific (easy) areas. For this purpose among others, sharing of data, knowledge, technology and resources would play a major role as it's the collective efforts that will make a change.

In the end, Engr. Sharif extended thanks to all for coming together to jointly plan the prosperity of the country.

Speaking next, the Deputy Minister MRRD, Mr. - thanked the group on behalf of MRRD. He expressed conformity with the elements highlighted by the Deputy Minister MAAH. He also underscored the importance of planning and stressed the need for joint strategy for the three ministries. Stating about the past practices, he said that planning was done in the offices and there were mismatches between the needs of the people and the interventions implemented by the government in the past. In order to avoid repetition of such mistake, the current system of planning, the Deputy Minister stated that MRRD has introduced bottom-up problem identification and needs assessment. For this purpose a team of experts went to each region and MRRD now has a bout 1500 p rojects identified.

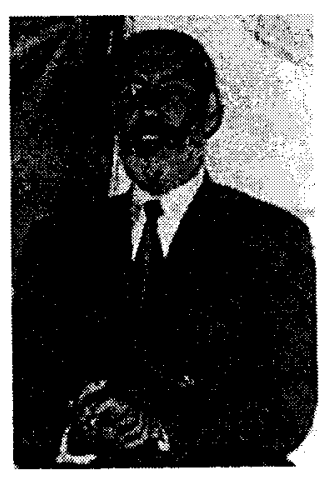
The ministry has initiated the resource mobilization campaign and is awaiting funds release. 
He also emphasized that government alone can not solve all the problems. However, to bring about any significant change, the three ministries would have to closely work together, and, MRRD will support MAAH and MIWRE for projects of their sphere, thus, creating an amplified impact of the joint interventions - compared to unconnected efforts carried out individually.

In the end, he hoped that a clear picture for future will emerge from the workshop, and wished success to the participants and the workshop.
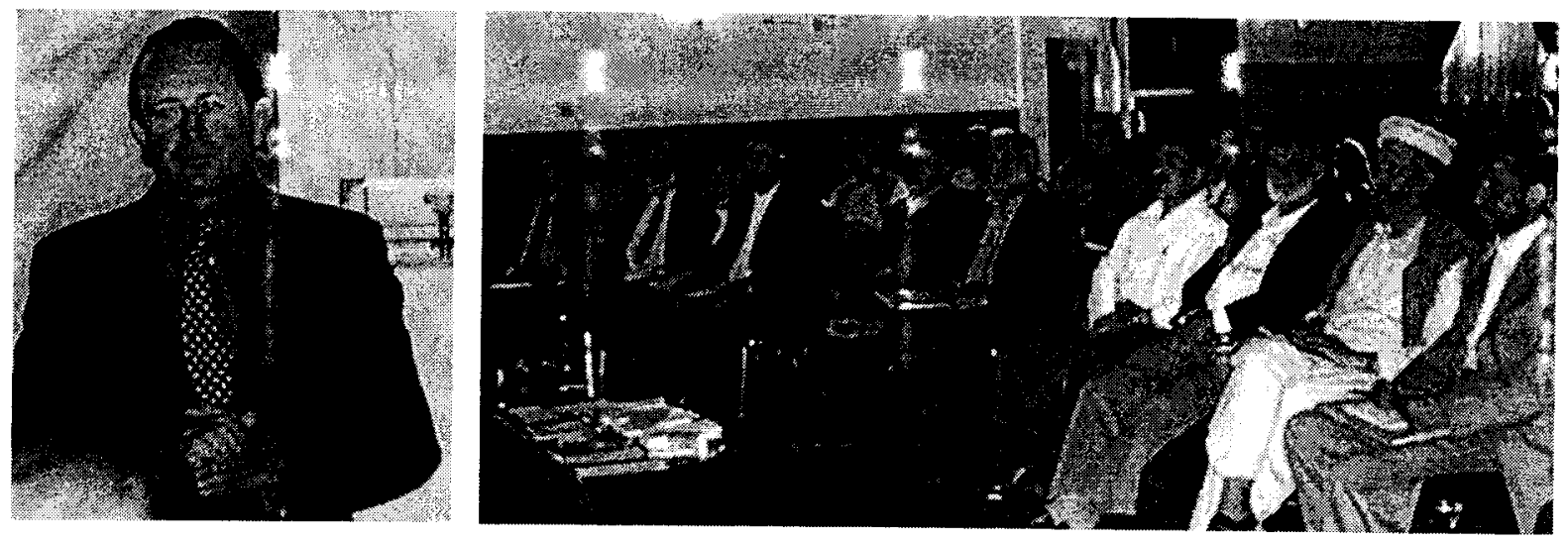

Mr. Serge Verniau, FAO Representative for Afghanistan extended warm welcome to the deputy ministers and the participants. Introducing the FAO, it was stated that the organization has 183 countries and European Union as its members. He highlighted that the organization is bound to work with local institutions and the process of integration into line ministries has already started. Consequently, the government buildings are being rehabilitated and some new blocks are being constructed to work very closely with the civil servants. This calls for change in mentality and efforts are made for it too, though it takes time but we are confident and will succeed soon.

In Afghanistan, FAO does not have any specific agenda; it belongs to the farmers and is at service to the local population. FAO will go all along all the way with Afghans to bring about significant change; this is not an opportunistic organization.

Towards this objective, recently the Agriculture Conference was organized and as a follow-up of the event, FAO and the deputy ministries from the three ministries meet fortnightly to review the cooperation and the progress of activities.

Stating the purpose of the workshops, Mr. Verniau stated that FAO's is interested to facilitate/assist the three ministries under the interim government to discuss together the problems and prepare a strategic plan. This is the last workshop in the series; similar workshops have been carried out in the regions.

Furthermore, he stated that the workshop is of unique nature and very demand and lot of work should be expected. He encouraged the participant to get fully involved in the activities/exercises as these will greatly help in building the capacities. Mr. Verniau ended his address with thanks and good wishes to the workshop.

Finally, Engr. Abdul Rahim, Senior National Programme Officer briefed the workshop participants about the five regional workshops conducted under the same theme. He apprised the participants that in those workshops over 200 senior department staffs and significant number of NGO representatives jointly carried out the detailed analysis of the provincial problems that formed the basis for the regional strategies. However, the current (Ministry Level Workshop) event is organized exclusively for the ministries to discuss the national level issues and to make a strategy that helps in e nhancing the support from the central government and that the outcomes could help identify the issues for policy making.

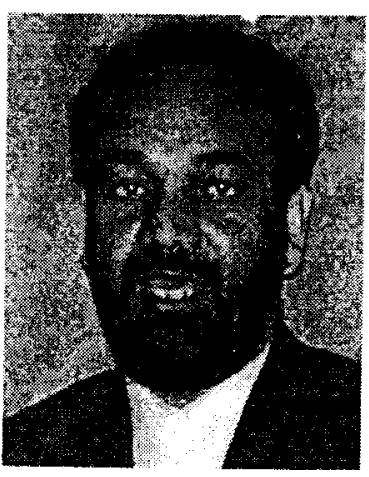




\section{Role of State}

Immediately after the opening speeches through a moderated discussion, taking advantage of the presence of the dignitaries (deputy ministers and FAOR), the workshop participants were facilitated to discuss the role of state. The exercise was planned to highlight the different role and obligations of the ministries vis-à-vis the departments at the provincial level. The group brainstormed their views as to what they think are the responsibilities that ministries are obliged to fulfi towards their respe stive sectors. Morec ver, the group also tiscussed the overa l objective that serves as the guiding principle that these roles lead to. Each element suggested was first discussed and understanding about the roles was enhanced. The agreed upon roles are presented below:

\section{Role of State}

- To provide everything!! « _-.- this is what people want and wish

- Develop / review national development framework

- Policies, laws, regulations and strategies for sectors

- Capacity building

- To act as monitor by doing:

- Needs assessment

- guidance

- supervision

- evaluation

- data / info gathering and analysis

- Overcome / counter sense of uncertainty and insecurity

- To create opportunities and provide means for development and prosperity (incl. fund raising)

- Coordination (of all developmental works)

- Quality control

\section{All the above for:}

a) Food security, and

b) Socio-economic development.

Initially the group unanimously held the state responsible to provide for each and every service and facility. The participants were of opinion that keeping the present situation of the country the government is supposed to deliver all goodies to the people. However, after a brief discussion 
about "how realistic is this expectation" and on sharing the insight about the role of a "modern" state, the workshop participants realized idealistic nature of the role (expectation).

Later, through facilitation, more specific tasks were identified, discussed and agreed upon. The session also resulted in clearer understanding for the ministry staff that:

- Ministries are the "sector managers" and not implementers.

- Each sector has s ,ecific resources to nanage and develo s. For example, For sts are one such resource for with MAAH is responsible and its management includes:

- Protection, incl. preventions of smuggling

- Conservation, incl. promotion of efficient use as well as alternatives

- Development, reforestation and aforestation

- The involved bodies in each sector are: the government institutions, academia, nongovernmental organizations, private sector, research organizations, etc.

- Departments are the implementation (and enforcement) arms of the governments.

The understanding reached during the session was carried forward to the step where planning framework was developed as guidelines for the analyses and strategy planning.

Since this exercise changed the entry into the planning task, the workshop skipped the writing of the personal expectation from the workshop.

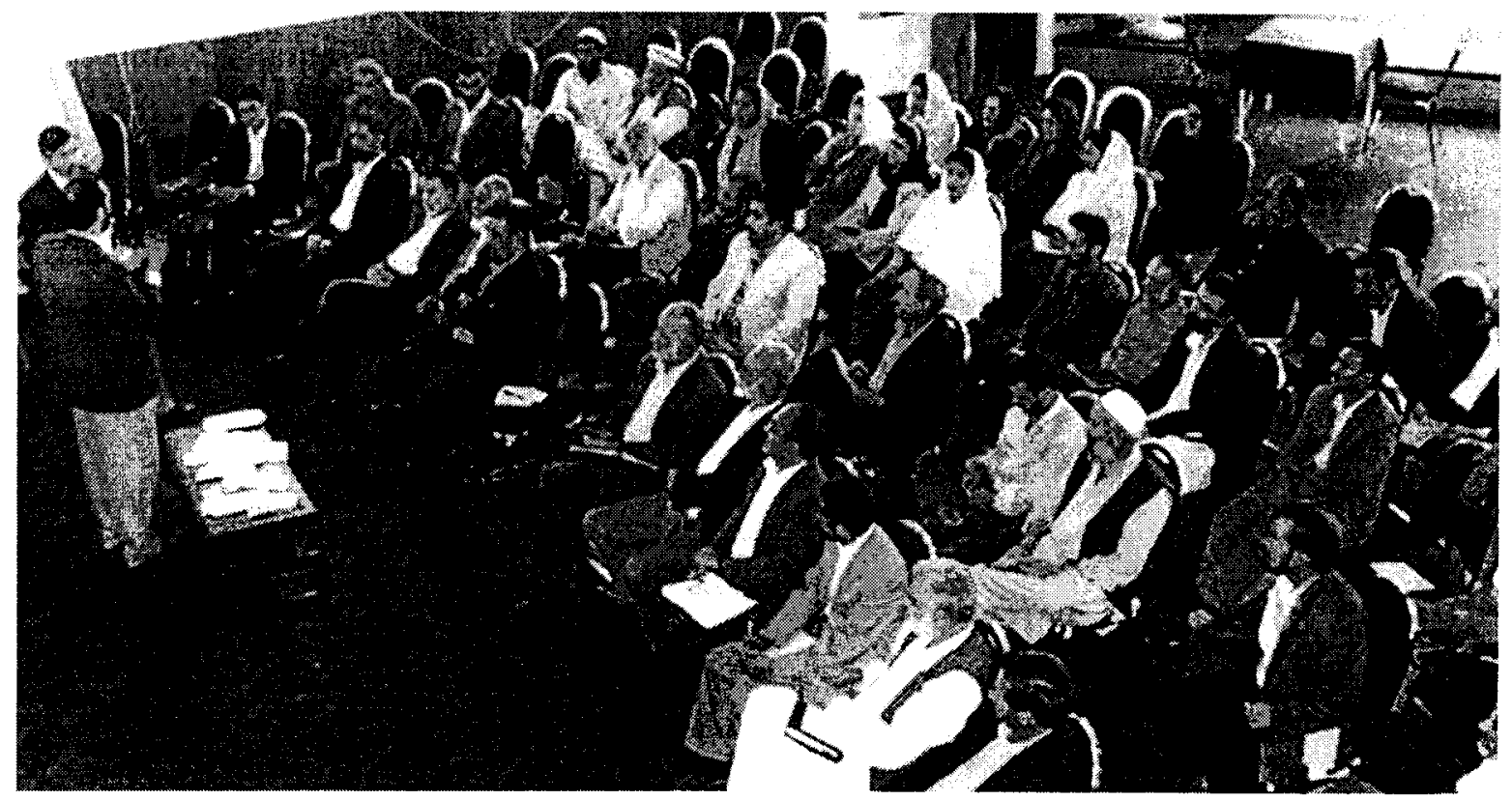

Introduction to Workshop Methodology \& Participants

Later, workshop timings were worked out to accommodate prayer timings together with the lunch and tea breaks. Later, the chart and card technique was explained to the participants.

A brief overview of the steps of the ZOPP method and the design of the PPM were explained. In addition to this brief introduction, before the start of each step detailed understanding into how to do the exercises were also given.

Later, the participants introduced themselves verbally by giving their names, designation and organisation. A complete list of workshop participants is presented in annex \#1. 


\section{Planning Framework}

The earlier discussions about the role of state and that the current workshop was charged to develop a joint strategy for the three ministries, the broad parameters for the planning tasks were more or less understood by the group. However, to help maintain the focus on the subject matter of the workshop, participants were facilitated to agree upon the planning framework.

The framework underscored the precincts for all subsequent works carried out in the workshop culminating with the strategy. The session aided in gaining clearer understanding by the group on the factors that will be addressed by the workshop for the planning purposes. At the same time, it also highlights the key concerns the people had in mind for the analysis of situation.

United Nations - Food \& Agricultural Organization, Afghanistan

PLANNING FRAMEWORK

FOR AGRICULTURAL \& RURAL DEVELOPMENT

MINISTRY LEVEL WORKSHOP

SCOPE: Ministries of :

a) Agriculture and Animal Husbandry (MAAH)

b) Irrigation, Water Resources and Environment (MIWRE)

C) Rural Rehabilitation and Development (MRRD)

Factors: - Technical Aspects

- Non-technical Aspects

Sectors: Agriculture

* Rural Development

\begin{tabular}{|l|l|}
\hline Sub-Sectors & Crosscutting Elements \\
\hline$>$ Food security & - Investment promotion \\
$>$ Promotion of Private Sector & - Capacity building \\
$>$ Marketing & - Institution strengthening and \\
$>$ Natural Resource & building \\
Management (Environment) & - Water resource \\
- Land resource & - Technology (tools) \\
- Human resource & - Inputs \\
$>$ Resource mobilization & - What resources are needed? \\
- Sources? & - Awareness \\
- How? & \\
(fund raising) & \\
Data / info management & \\
\hline
\end{tabular}




\section{Problem Analysis}

After the agreement on "planning framework", the workshop continued into the much awaited analysis of problems. The purpose of the problem analysis is:

Identify and analyse the major problems surrounding the given condition. Arrive at a group consensus about the core problem, which describes the cent al point of the ove all problematic cor tition, and visualise the cause-effect relationships in a Problem Tree.

To begin with, each participant was given the opportunity to write one problems on a card which they considered to be an important problem. While sharing the submissions of the first round of brainstorming, the clustering of corresponding cards highlighted the six centres of attention; these were:

- Agriculture

- Irrigation

- Private Sector Participation (in development)

- Rural Communities, and

- Government Institutions

Unlike the regional workshops, separate in-depth analyses of the "forests" and "livestock" subsectors were not performed. The group agreed that the amount of details already pointed out in the regional workshops needs not be repeated. They were of the opinion that major and macro level problems be tackled in the current workshop.

The next step was to identify a core-problem of the situation. This proved to be an arduous task for the group - all of whom were having their first exposure to such exercise. Attempts made for the formulation of core-problem were not successful at the first instance. The second attempt was made after the first group work on the causes to the major problems. With the facilitation the group finally agreed on the following statement as core-problem:

\section{"resources and support systems for rehabilitation and development of production (are) inappropriate"}

The plenary was then divided into five subgroups, one each for principal causes (areas) of the core-problem. The assigned task was to continue with the problem analysis in subgroups for allocated topic in greater details and in their own languages. This not only resulted in expeditious completion but generated wider understanding of the situation. The outcomes of the group work were shared with the plenary where certain adjustments were made to the final product.

By the end of second day the workshop succeeded in completing the Problem Tree. The next page presents the core problem, all

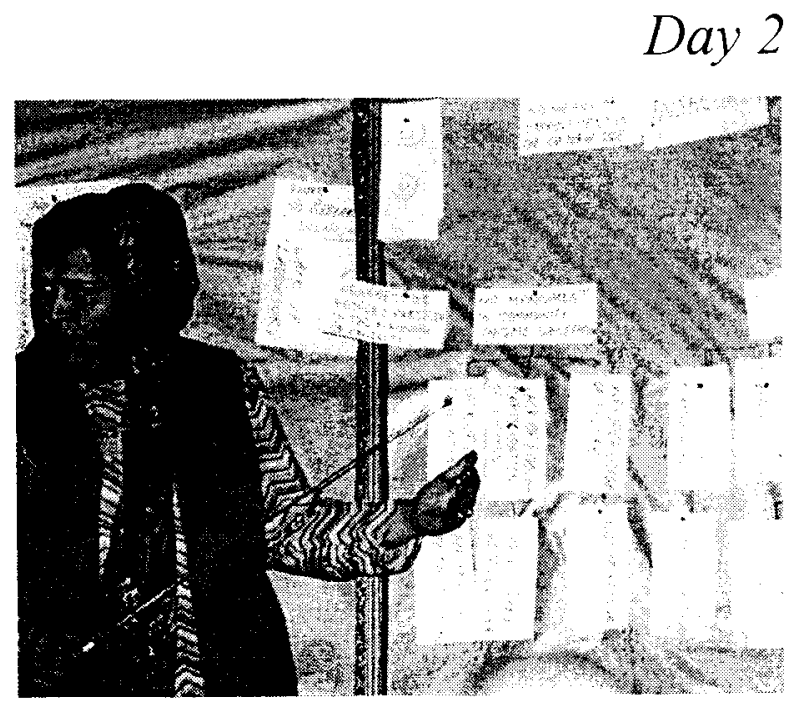
the identified effects and major problems. The causes to the major problems are presented on the subsequent pages; these are the resultant charts of the group work analysis. 


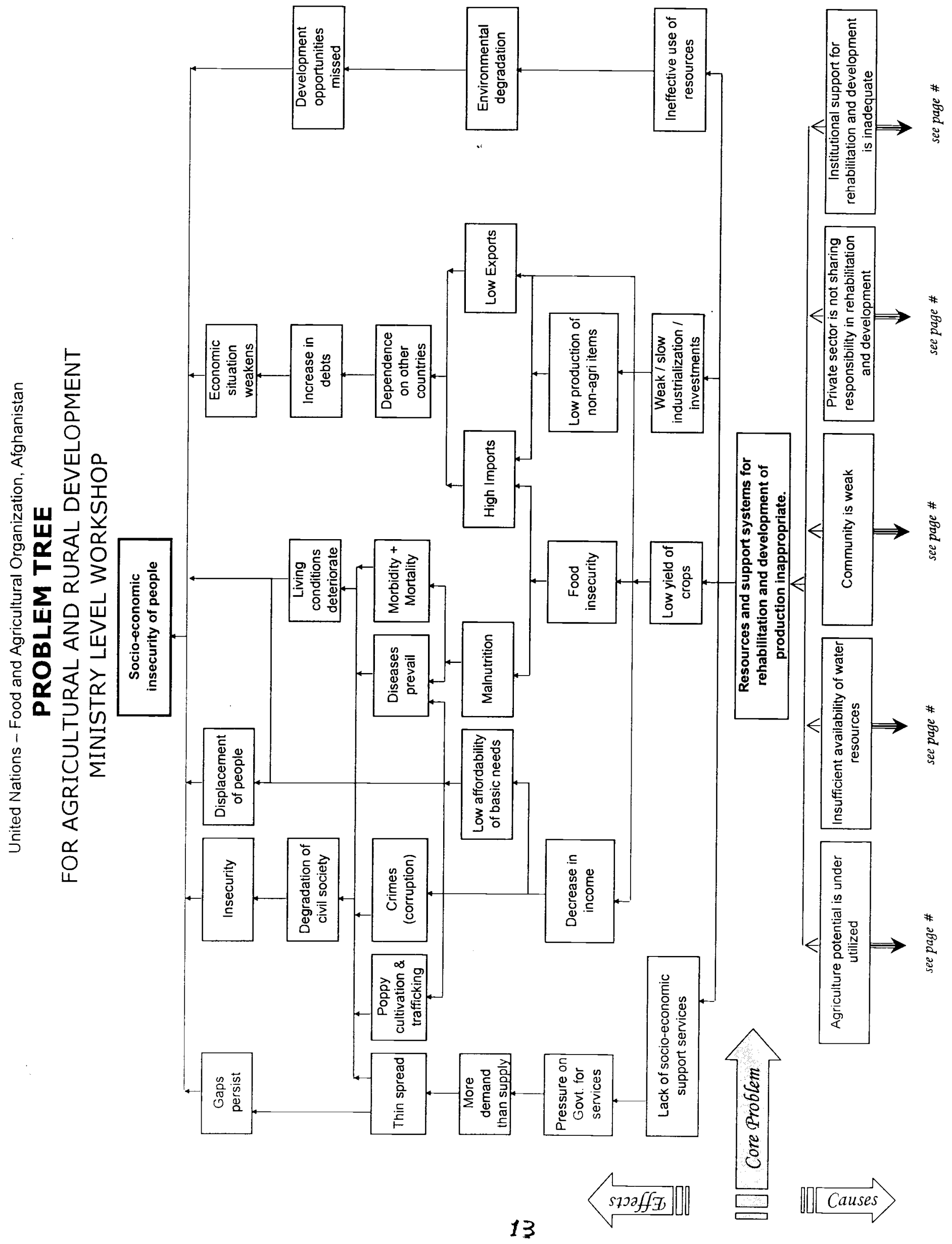




\section{Objectives Analysis}

After the problem analysis, which described the depressing existing situation, an objective analysis was made. The purpose of the objective analysis is:

\section{All the problem statements in the Problem Tree are transformed into positive, describing the future situation that will be achieved by solving the problems.}

The guiding principles for formulation of objectives were to assess the statements for a) it is desirable, and b) is realistically achievable. Also, alternative solutions were to be found for the problems that were insoluble or that the objectives were inexpedient. Furthermore, additional objectives for achieving the ends (stated at next higher level) were to be added during the analysis to complete the means-ends relationship.

At first, in plenary, a handful of objectives were formulated to generate understanding of the task. Later, the sub-groups worked out the objective statement for the assigned parts of the problem tree.

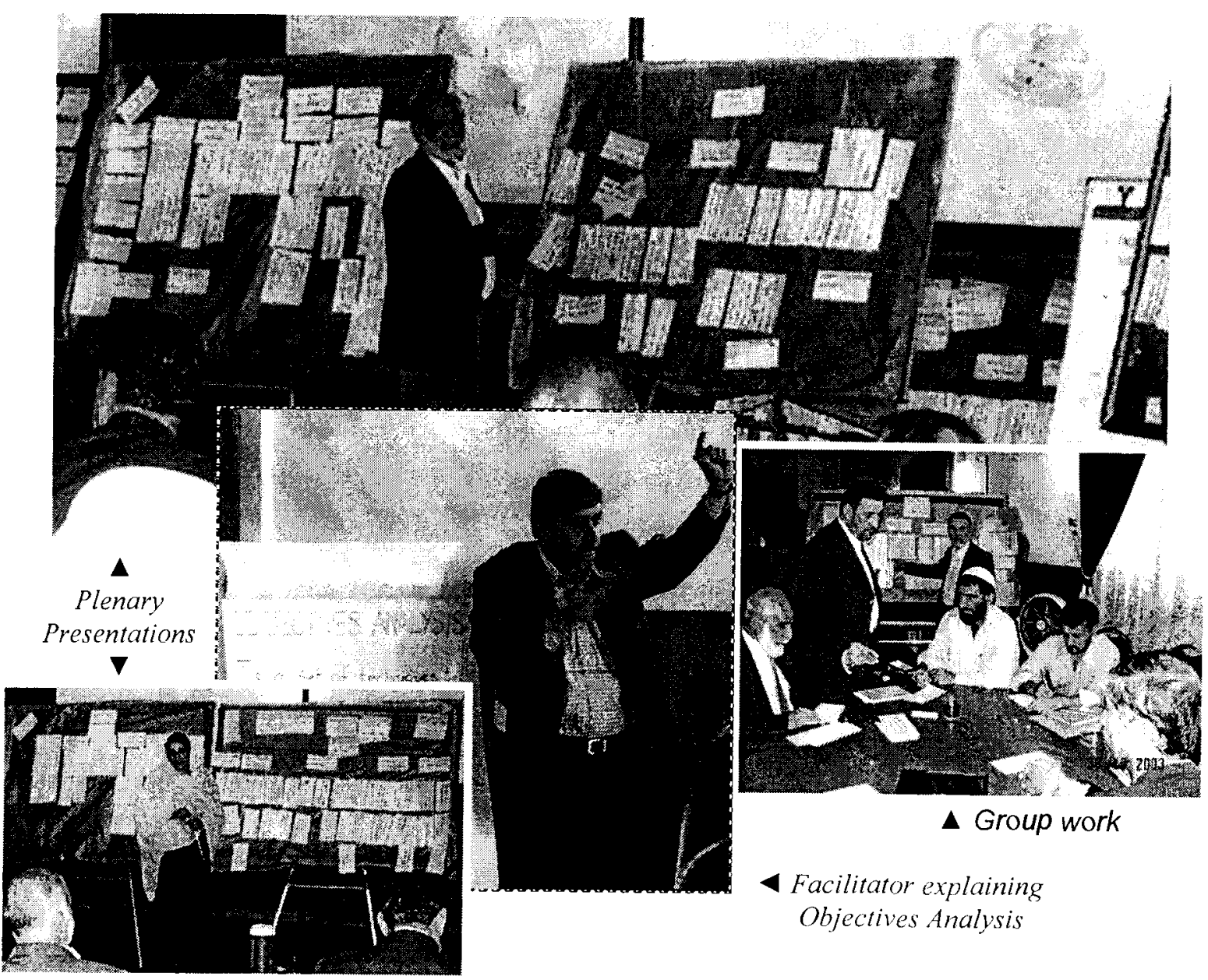

During the plenary presentations of the sub-group works, the whole of objective tree was verified for completeness and agreed upon suggestions were added to the analysis.

The step was considered as a welcome change by the participants since they were no longer talking about the negative situation but instead about future state which the strategy would achieve.

The Objective Tree constructed by the participants is presented on the following pages. 

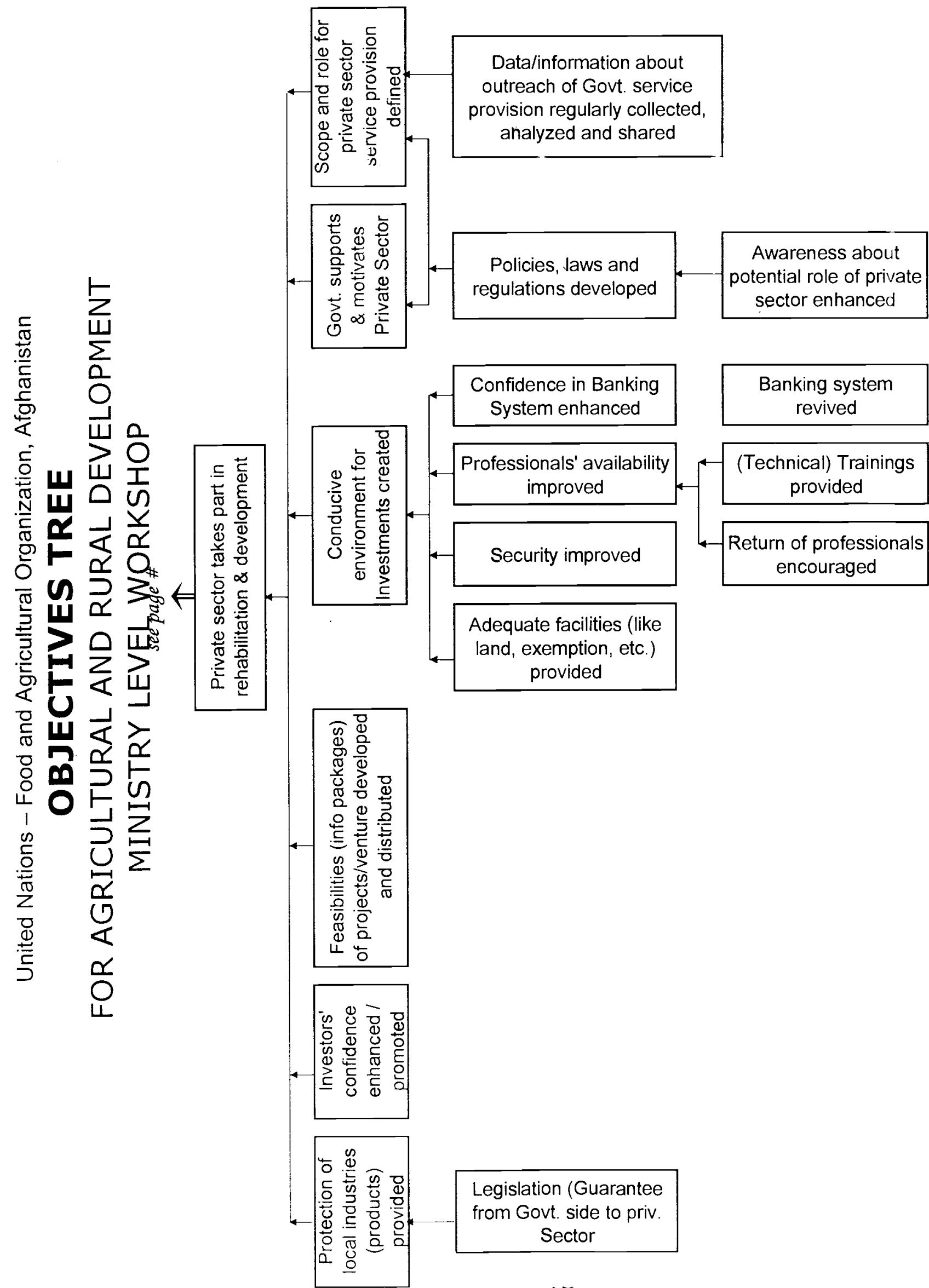

Legislation (Guarantee from Govt. side to priv. Sector 


\section{Stakeholders Analysis}

The wide-ranging intervention requirements concluded by the Objectives Analysis highlighted the need to swot up various stakeholders.
Analyse the strengths/potential and role/obligation of all individuals, groups and organizations connected with the objectives. The information generated in this analysis will help in deciding the future partnerships and it.volvement of wider yroup and its strengihs to benefit implenientation.

Through brainstorming on cards, workshop participants suggested various involved parties to the strategy. These were later categorized into the following five categories:

- Government organizations

- Community

- Private Sector

- UN Agencies

- Donors, NGOs (local and international) and Research Organizations

Afterwards, equal number of sub-groups were constituted to carryout rudimentary study of each stakeholder.

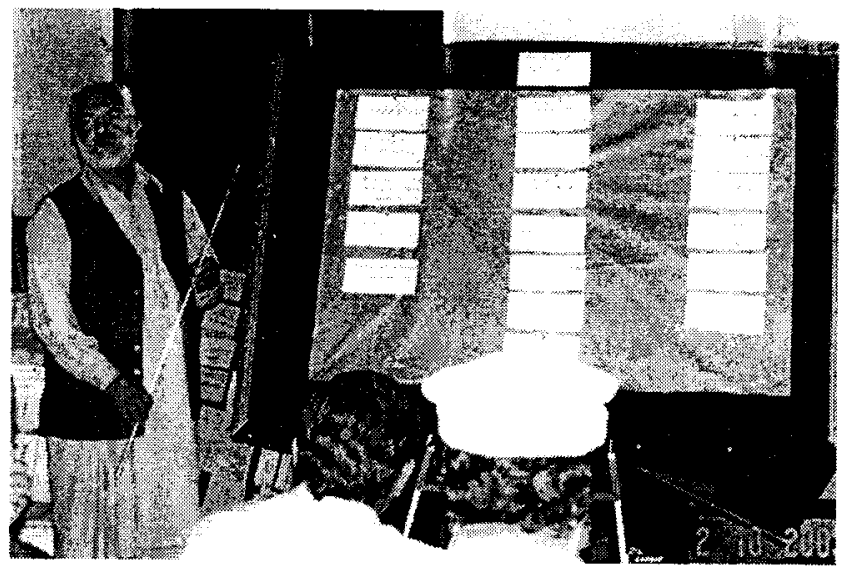

Day 4

Fourth day of the workshop began with the group work session where the participants deliberated on various stakeholders and their strengths and anticipated role towards the strategy. The group faced difficulties in specifying the strengths/potential in particular; also, obstacles were met in stating details about others - like private sector, NGOs, etc. was observed.

The results of the group-work were presented to the plenary, in due course, adjustments suggested by the participants were accommodated into the final product.

Afterwards, the w orkshop participants were invited to discuss the issue of "ownership" of the strategy; i.e., who takes the responsibility of pursuing it (with the Government and the donors), as well as to seek and acquire support and take charge to realize it.

Participants were of the view that no single organization can shoulder the responsibility and suggested that key s takeholders from Government, Community and UN o rganizations should assume responsibility of the strategy.

Consensus was reached on the following group of stakeholders to equally share the onus.

\begin{tabular}{|c|c|c|}
\hline Government & Community & UN Organizations \\
\hline $\begin{array}{l}\text { - Ministry of Agriculture \& Animal Husbandry } \\
\text { - Ministry of Rural Rehabilitation \& Development. } \\
\text { - Ministry of Irrigation, Water Resources and } \\
\text { Environment }\end{array}$ & $\begin{array}{l}\text { - Community } \\
\text { Leaders } \\
\text { - Shuras }\end{array}$ & $\begin{array}{l}\text { - } \text { FAO } \\
\text { - UNAMA } \\
\text { - UNDP }\end{array}$ \\
\hline
\end{tabular}

Following pages present the output of this brief analysis. 


\section{FOR AGRICULTURAL \& RURAL DEVELOPMENT MINISTRY LEVEL WORKSHOP}

\section{GOVERNMENTAL INST.TUTIONS}

\begin{tabular}{|c|c|c|}
\hline Stakeholders & Strength/Potential & Role/ Obligation towards Strategy \\
\hline $\begin{array}{l}\text { Ministry of Agriculture } \\
\text { and Animal Husbandry } \\
\text { (MAAH) * }\end{array}$ & $\begin{array}{l}\text { Land, technical staff, } \\
\text { technical equipment and } \\
\text { experience. } \\
\text { Information on regulation, } \\
\text { statistics. } \\
\text { - Lab, storage facilities, } \\
\text { improved seed and } \\
\text { research stations. } \\
\text { - Cooperatives, plant and } \\
\text { animal protection. }\end{array}$ & $\begin{array}{l}\text { - Increasing of plant and animal } \\
\text { production for achieving self- } \\
\text { sufficiency. } \\
\text { - } \quad \text { Promote non-utilization of agri. } \\
\text { Land for other purposes. } \\
\text { - Facilitate the coordination of } \\
\text { different organizations working on } \\
\text { agriculture. } \\
\text { - Development of regulation to } \\
\text { prevent land fragmentation. } \\
\text { - Prepare resource (land, forest) } \\
\text { management plans. } \\
\text { - Encouragement of privatization. } \\
\text { - Support agricultural cooperatives. }\end{array}$ \\
\hline $\begin{array}{l}\text { Ministry of Irrigation, } \\
\text { Water Resources and } \\
\text { Environment } \\
\left(\text { MIWRE) }{ }^{*}\right.\end{array}$ & $\begin{array}{l}\text { - Water resources } \\
\text { - Survey and design of } \\
\text { Hydro-structures. } \\
\text { - } \text { Qualified technical } \\
\text { personnel. } \\
\text { - Have water resources data. } \\
\text { - Transfer of experience to } \\
\text { Mirabs and water user. } \\
\text { - Soil and water analysis } \\
\text { laboratories. } \\
\text { - Technical facilities. } \\
\text { - Natural resources } \\
\text { conservation } \\
\end{array}$ & $\begin{array}{l}\text { - Drinking water provision. } \\
\text { - Water for agriculture. } \\
\text { - Navigation. } \\
\text { - } \text { Electro-hydro power. } \\
\text { - } \text { water resources. } \\
\text { - Do country-wide needs } \\
\text { assessment. } \\
\text { - Close coordination with MRRD } \\
\text { To coordinate all iNGOs and } \\
\text { donors. }\end{array}$ \\
\hline $\begin{array}{l}\text { Ministry of Rural } \\
\text { Rehabilitation and } \\
\text { Development (MRRD)* }\end{array}$ & $\begin{array}{l}\text { Information on community } \\
\text { (villages). } \\
\text { - Laws and regulation. } \\
\text { - Technical staff and budget. }\end{array}$ & $\begin{array}{l}\text { Building capacities of the rural } \\
\text { communities for reaching prosper } \\
\text { future. } \\
\text { - To construct pony tracks/roads for } \\
\text { agriculture marketing. } \\
\text { - Livelihood needs assessment. } \\
\text { - Actively promote family planning } \\
\text { - Identify off farm income } \\
\text { opportunities. } \\
\text { - Support establishment of micro- } \\
\text { enterprises. } \\
\text { Training of professional (incl. } \\
\text { literacy training) }\end{array}$ \\
\hline
\end{tabular}


United Nations - Food \& Agricultural Organization, Afghanistan

STAKEHOLDER ANALYSIS

\section{FOR AGRICULTURAL \& RURAL DEVELOPMENT MINISTRY LEVEL WORKSHOP}

\section{GOVERNMENTAL INSTITUTIONS}

\begin{tabular}{|c|c|c|}
\hline Stakeholders & Strength/Potential & Role/ Obligation towards Strategy \\
\hline Ministry of Information. & $\begin{array}{l}\text { - Technical staff in } \\
\text { communication. } \\
\text { - Facilities for information } \\
\text { transmission to the } \\
\text { community. }\end{array}$ & Publication of information. \\
\hline $\begin{array}{l}\text { Ministry of Finance } \\
\text { (Allocation and } \\
\text { Disbursement) }\end{array}$ & $\begin{array}{l}\text { Preparation of finance } \\
\text { policy. } \\
\text { Control and checking of } \\
\text { financial utilization. } \\
\end{array}$ & $\begin{array}{l}\text { - Provision of facilities for financial } \\
\text { solution. } \\
\text { Establish seminars for increase of } \\
\text { awareness. }\end{array}$ \\
\hline $\begin{array}{l}\text { Ministry of Higher } \\
\text { Education }\end{array}$ & $\begin{array}{l}\text { Technical and professional } \\
\text { staff. }\end{array}$ & $\begin{array}{l}\text { - Qualify personnel. } \\
\text { - Improving existing curricula to the } \\
\text { needs of people (and time). }\end{array}$ \\
\hline $\begin{array}{l}\text { Ministry of Education } \\
\text { (Primary and Secondary } \\
\text { Education) }\end{array}$ & $\begin{array}{l}\text { Schools. } \\
\text { - Teachers and teaching } \\
\text { facilities. } \\
\end{array}$ & $\begin{array}{l}\text { General education. } \\
\text { - Education of technical staff. }\end{array}$ \\
\hline Ministry of Law & - $\quad$ Preparation of laws & - Implementation of laws. \\
\hline Ministry of Commerce & $\begin{array}{ll}\text { - } & \text { Technical staff. } \\
\text { - Offices and storages. } \\
\text { - } \\
\text { Regulation of international } \\
\text { contacts. } \\
\end{array}$ & $\begin{array}{l}\text { - Facilitate in import and export } \\
\text { - } \quad \text { Provide facilities and info. }\end{array}$ \\
\hline $\begin{array}{l}\text { Department of } \\
\text { Meteorology }\end{array}$ & - $\quad$ Technical staff. & $\begin{array}{l}\text { - Weather forecast. } \\
\text { GIS meteorological classification } \\
\text { and station establishment. } \\
\text { - Regularly share these information } \\
\text { with other concerned ministries } \\
\text { and organizations. }\end{array}$ \\
\hline $\begin{array}{l}\text { Ministry of } \\
\text { Communication }\end{array}$ & $\begin{array}{ll}\text { - } & \text { Technical staff. } \\
\text { - Technical equipment. } \\
\text { - } \\
\end{array}$ & $\begin{array}{l}\text { Transferring of information and } \\
\text { messages. } \\
\text { - Provide communication facilities. }\end{array}$ \\
\hline Ministry of Public Health & $\begin{array}{l}\text { - Hospitals. } \\
\text { - Medical staff } \\
\text { - } \text { Medicine. } \\
\text { - Water testing laboratories. }\end{array}$ & $\begin{array}{l}\text { - Testing of water quality. } \\
\text { - } \quad \text { Care of Health } \\
\text { - Food quality control. }\end{array}$ \\
\hline $\begin{array}{l}\text { Ministry of Interior (Dept. } \\
\text { of Security) }\end{array}$ & $\begin{array}{l}\text { - Security staff. } \\
\text { - Facilities and power of } \\
\text { implementation of laws. }\end{array}$ & - Security for works and workers. \\
\hline
\end{tabular}


United Nations - Food \& Agricultural Organization, Afghanistan

STAKEHOLDER ANALYSIS

FOR AGRICULTURAL \& RURAL DEVELOPMENT MINISTRY LEVEL WORKSHOP

\section{GOIERNMENT $/$ L INSTITUTIONS}

\begin{tabular}{|l|l|l|}
\hline Stakeholders & Strength/Potential & Role/ Obligation towards Strategy \\
\hline Ministry of Planning & $\begin{array}{l}\bullet \text { Technical staff. } \\
\text { Provision of budget for } \\
\text { implementation of projects } \\
\text { Rules and regulation } \\
\text { according to the planning. }\end{array}$ & $\begin{array}{l}\bullet \text { Provision of facilities for planning } \\
\text { development projects }\end{array}$ \\
\hline Municipality Dept. & $\begin{array}{l}\text { Commodity price control. } \\
\text { Rules and regulation for } \\
\text { estimation of costs and its } \\
\text { control. }\end{array}$ & $\bullet$ Social services. \\
\hline
\end{tabular}




\section{United Nations - Food \& Agricultural Organization, Afghanistan STAKEHOLDER ANALYSIS \\ FOR AGRICULTURAL \& RURAL DEVELOPMENT MINISTRY LEVEL WORKSHOP}

\section{COMMUNITY}

\begin{tabular}{|c|c|c|}
\hline Stakeholders & Strength/Potential & Role/ Obligation towards the Strategy \\
\hline Community Leaders* & $\begin{array}{l}\text { - Community mobilization } \\
\text { and control }\end{array}$ & - Decision making \\
\hline Mullahs & - Ideologically dominance & $\begin{array}{l}\text { - Pursuing community support and } \\
\text { monitor }\end{array}$ \\
\hline Teachers & $\begin{array}{l}\text { - Enlightening the new } \\
\text { generation }\end{array}$ & $\begin{array}{l}\text { - Education and civilization. } \\
\text { - Civil services }\end{array}$ \\
\hline Shura* & $\begin{array}{l}\text { - Motivation of } \\
\text { participation }\end{array}$ & $\begin{array}{l}\text { - Facilitating and solving problems. } \\
\text { - Implementation process }\end{array}$ \\
\hline Commanders & - Military dominance & - Disarming and invest in rehabilitation \\
\hline Farmers (Land owners) & $\begin{array}{l}\text { - Owing the land } \\
\text { - Technical knowledge }\end{array}$ & $\begin{array}{l}\text { Increase technical knowledge. } \\
\text { - Increase agricultural production. }\end{array}$ \\
\hline Mirabs & $\begin{array}{l}\text { - Water distribution } \\
\text { - Conflict solving }\end{array}$ & - Regulating water resources \\
\hline Refugees & $\begin{array}{l}\text { - Empowerment of the } \\
\text { rehabilitating powers }\end{array}$ & $\begin{array}{l}\text { - Technical information } \\
\text { - Investment } \\
\text { - Production improvement. }\end{array}$ \\
\hline Handicaps & - Mental forces & $\begin{array}{l}\text { - Development of the handicraft } \\
\text { production }\end{array}$ \\
\hline Land Lords & $\begin{array}{l}\text { - Own agri. Lands. } \\
\text { - Have money } \\
\text { - Decide on land use }\end{array}$ & $\begin{array}{l}\text { Landlords invest in improvement of } \\
\text { farming, e.g. machinery, land leveling, } \\
\text { provide credit. } \\
\text { - Do large scale farming. }\end{array}$ \\
\hline Women & $\begin{array}{l}\text { - Reducing the gender } \\
\text { inequity }\end{array}$ & $\begin{array}{l}\text { - Participation in decision making } \\
\text { - Maintaining the relationship among } \\
\text { community. }\end{array}$ \\
\hline $\begin{array}{l}\text { Individual } \\
\text { professionals }\end{array}$ & - Technical development & $\begin{array}{l}\text { - Active participation in community } \\
\text { development. }\end{array}$ \\
\hline
\end{tabular}


United Nations - Food \& Agricultural Organization, Afghanistan

STAKEHOLDER ANALYSIS

FOR AGRICULTURAL \& RURAL DEVELOPMENT

MINISTRY LEVEL WORKSHOP

\section{PRIVATE SECTOR}

\begin{tabular}{|c|c|c|}
\hline Stakeholders & Strength/Potential & Role/ Obligation towards the Strategy \\
\hline Investor & - Money potential & $\begin{array}{l}\text { Establishment of industrial factories } \\
\text { and companies. }\end{array}$ \\
\hline Traders & $\begin{array}{l}\text { - Import export } \\
\text { knowledge }\end{array}$ & $\begin{array}{l}\text { - Promote local products. } \\
\text { - Facilities for the services. }\end{array}$ \\
\hline Enterprises & - Production of material & $\begin{array}{l}\text { - Help farmers in market. } \\
\text { - Give proper price to farmers. } \\
\text { - Avoid monopolization. }\end{array}$ \\
\hline $\begin{array}{l}\text { Agricultural } \\
\text { Development Bank }\end{array}$ & - Credit facilities & $\begin{array}{l}\text { - Provide credit for farmers. } \\
\text { - Support of cooperatives. }\end{array}$ \\
\hline Neighboring countries & $\begin{array}{l}\text { - Exchange of material. } \\
\text { - Import and export }\end{array}$ & $\begin{array}{l}\text { - Inputs/outputs. } \\
\text { - Creating new markets } \\
\text { - Facilities for traders. }\end{array}$ \\
\hline Transporters & - Transportation & $\begin{array}{l}\text { - Transportation of materials. } \\
\text { - Timely providing equipments. }\end{array}$ \\
\hline Labor associations & $\begin{array}{l}\text { - Human power } \\
\text { - Technical staff }\end{array}$ & - Direction for production \\
\hline Cooperatives & $\begin{array}{l}\text { - Coordination } \\
\text { - Cooperation. }\end{array}$ & $\begin{array}{l}\text { - } \text { Mobilizing farmers. } \\
\text { - Marketing services }\end{array}$ \\
\hline $\begin{array}{l}\text { Improved seed } \\
\text { corporations }\end{array}$ & $\begin{array}{l}\text { - Providing improved } \\
\text { seeds. }\end{array}$ & - Improvement of agricultural sector. \\
\hline Professional unions & $\begin{array}{l}\text { - Preparing } \\
\text { professionals }\end{array}$ & - Improvement of quality and quantity. \\
\hline
\end{tabular}




\section{FOR AGRICULTURAL \& RURAL DEVELOPMENT MINISTRY LEVEL WORKSHOP}

\section{UNITED NATIONS ORGANIZATIONS}

\begin{tabular}{|c|c|c|}
\hline Stakeholders & Strength/Potential & Role/ Obligation towards the Strategy \\
\hline$\overline{\text { COMMON }}$ & $\begin{array}{l}\text { Respected by } \\
\text { Government and } \\
\text { people. } \\
\text { - Experience of } \\
\text { reconstruction / } \\
\text { development. } \\
\text { - Technical know-how. } \\
\text { - Experts } \\
\text { - Resources. }\end{array}$ & $\begin{array}{l}\text { - To forget their own political interests. } \\
\text { - Support and facilitate public-private partnership for } \\
\text { service provision. } \\
\text { - Transparency and accountability of their own } \\
\text { works. } \\
\text { - Do institution building } \\
\text { - Propagate strategy and seek support for it. } \\
\text { - All UN agencies to coordinate their works/ projects } \\
\text { under strategy. } \\
\text { - Equal distribution (attention) to all parts of } \\
\text { Afghanistan. }\end{array}$ \\
\hline UNOPS & $\begin{array}{l}\text { - Runs small projects } \\
\text { - Help small social } \\
\text { project } \\
\text { - Monitor's project } \\
\text { activity }\end{array}$ & $\begin{array}{l}\text { - Runs small project in agriculture and irrigation for } \\
\text { community } \\
\text { - Helps small social projects in agriculture, irrigation } \\
\text { and rural development. } \\
\text { - Monitors project activities in agriculture, irrigation } \\
\text { and community. }\end{array}$ \\
\hline UNAMA* & $\begin{array}{l}\text { - Disarmament } \\
\text { - Transportation } \\
\text { - National defence } \\
\text { - Organizing all political } \\
\text { events }\end{array}$ & $\begin{array}{l}\text { - To control all political works } \\
\text { - Transportation for community. }\end{array}$ \\
\hline UNICEF & $\begin{array}{l}\text { - Training course } \\
\text { - Helps to cover } \\
\text { malnutrition } \\
\text { - Training, capacity } \\
\text { building } \\
\text { - Vaccination } \\
\text { campaigns. } \\
\end{array}$ & $\begin{array}{l}\text { - Training courses for rural population. } \\
\text { - Helps to cover malnutrition in villages } \\
\text { - Training, capacity building in rural society } \\
\text { - Vaccination campaigns for animal + children. }\end{array}$ \\
\hline$\overline{\mathrm{WHO}}$ & $\begin{array}{l}\text { - Helps in human health } \\
\text { - Helps home } \\
\text { management } \\
\text { - Water and sanitation } \\
\text { - Drinking water }\end{array}$ & $\begin{array}{l}\text { - Helps in human health in village centers. } \\
\text { - Helps home management in villages } \\
\text { - Water and sanitation in rural areas } \\
\text { - Drinking water in villages }\end{array}$ \\
\hline UNDP* & $\begin{array}{l}\text { Rehabilitate } \\
\text { infrastructure } \\
\text { - Other social services. }\end{array}$ & $\begin{array}{l}\text { - Rehabilitate agriculture, community and irrigation } \\
\text { infrastructures. } \\
\text { - Other social services in rural areas. }\end{array}$ \\
\hline
\end{tabular}




\section{FOR AGRICULTURAL \& RURAL DEVELOPMENT MINISTRY LEVEL WORKSHOP}

\section{UNITED NATIONS ORGANIZATIONS}

\begin{tabular}{|c|c|c|}
\hline Stakeholders & Strength/Potential & Role/ Obligation towards the Strategy \\
\hline $\mathrm{FAO}^{*}$ & $\begin{array}{l}\text { - Agriculture services. } \\
\text { - Irrigation services. } \\
\text { - Community services } \\
\text { - Private sector } \\
\text { - Capacity building. }\end{array}$ & $\begin{array}{l}\text { - Agriculture and livestock services. } \\
\text { - Irrigation services } \\
\text { - Community services } \\
\text { - Private sector } \\
\text { - Capacity building. }\end{array}$ \\
\hline WFP & $\begin{array}{l}\text { - Food for work } \\
\text { - Food free distribution } \\
\text { - Free food distribution } \\
\text { in schools. } \\
\text { - Free food distribution } \\
\text { for widows. }\end{array}$ & $\begin{array}{l}\text { - Food for work in agriculture, irrigation and rural } \\
\text { development. } \\
\text { - Free food distribution in villages. } \\
\text { - Food for education } \\
\text { - Free food distribution in schools in villages. } \\
\text { - Free food distribution for widows in villages. }\end{array}$ \\
\hline$\overline{\text { UNHCR }}$ & $\begin{array}{l}\text { Helps internally } \\
\text { displaced and } \\
\text { returnees. } \\
\text { - Establishment of } \\
\text { camps. } \\
\text { - Transportation } \\
\text { - Shelter } \\
\end{array}$ & $\begin{array}{l}\text { - Helps internally displaced and returnees in the } \\
\text { villages. } \\
\text { - Establishment of camps on non-agriculture lands. } \\
\text { - Transportation villages } \\
\text { - Shelter for rural population. }\end{array}$ \\
\hline UNESCO & $\begin{array}{l}\text { - Working on historical } \\
\text { issues. }\end{array}$ & - To protect the national heritage. \\
\hline UNFEM & & \\
\hline $\begin{array}{l}\text { UNEP } \\
\text { UN HABITAT }\end{array}$ & $\begin{array}{l}\text { Not analysed due } \\
\text { to time constraints }\end{array}$ & $\begin{array}{l}\text { lysed due } \\
\text { constraints }\end{array}$ \\
\hline
\end{tabular}


United Nations - Food \& Agricultural Organization, Afghanistan

STAKEHOLDER ANALYSIS

\section{FOR AGRICULTURAL \& RURAL DEVELOPMENT MINISTRY LEVEL WORKSHOP}

\section{DONORS - NGOs - Ressarch Organizations}

\begin{tabular}{|c|c|c|c|}
\hline & Stakeholders & Strength/ Potential & Role/ Obligation towards Strategy \\
\hline 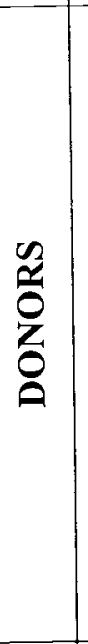 & $\begin{array}{ll} & \text { USAID } \\
\text { : } & \text { DFID } \\
\text { - } & \text { CIDA } \\
\text { - } & \text { RAMP } \\
\text { - } & \text { IFDC } \\
\text { - } & \text { JROCARE } \\
\text { - } & \text { NOVIB } \\
\text { - } & \text { DED } \\
\text { - } & \text { World } \\
& \text { Bank } \\
\end{array}$ & $\begin{array}{l}\text { - Funds and resources } \\
\text { - Technical staff. } \\
\text { - Capacity building. }\end{array}$ & $\begin{array}{l}\text { - Capacity building } \\
\text { (Remain) interested in development of } \\
\text { Afghanistan. }\end{array}$ \\
\hline 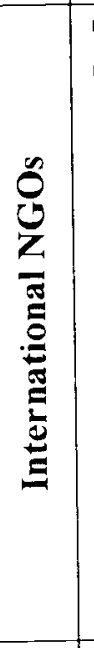 & $\begin{array}{l}\text { - UMCOR } \\
\text { - } \text { Oxfam } \\
\text { - } \text { IOM } \\
\text { - } \text { IAM } \\
\text { - } \text { DACARDA } \\
\text { - } \text { FHI } \\
\text { - } \text { MCPEA } \\
\text { - } \text { ACTED } \\
\text { - Jen Trust } \\
\text { - } \text { MDC. }\end{array}$ & $\begin{array}{l}\text { - Previous research records. } \\
\text { - Collection of new } \\
\text { information and } \\
\text { technologies. } \\
\text { - Technical staff. } \\
\text { - Research center. }\end{array}$ & $\begin{array}{l}\text { - Publication. } \\
\text { - Extension services. } \\
\text { - Training and recommendation. } \\
\text { - Monitoring and evaluation. } \\
\text { - Provide fund for strategy } \\
\text { - Capacity building, esp. for University } \\
\text { lecturers and for higher education in: } \\
\text { - History, } \\
\text { - Law, } \\
\text { - Politics, } \\
\text { - Literature, } \\
\text { - Economics, } \\
\text { - Sociology, etc. }\end{array}$ \\
\hline 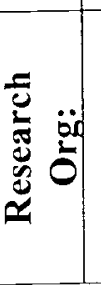 & $\begin{array}{l}\text { - CIMMYT } \\
\text { ICARDA }\end{array}$ & $\begin{array}{l}\text { Technical staff. } \\
\text { - International experts. } \\
\text { - Improved seeds. }\end{array}$ & $\begin{array}{l}\text { - Introducing new seed varieties. } \\
\text { - Seed multiplication. } \\
\text { - Scientific research in agriculture, } \\
\text { forestry. veterinary, geology, animal } \\
\text { husbandry } \\
\text { - History, law, politics. Etc. }\end{array}$ \\
\hline
\end{tabular}




\section{STAKEHOLDER ANALYSIS}

\section{FOR AGRICULTURAL \& RURAL DEVELOPMENT MINISTRY LEVEL WORKSHOP}

\section{DOIJORS - NGOs - Research Jrganizations}

\begin{tabular}{|c|c|c|c|}
\hline & Stakeholders & Strength/ Potential & Role/ Obligation towards Strategy \\
\hline 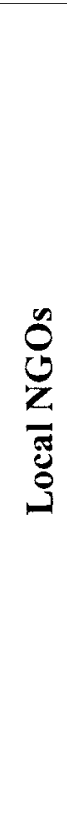 & $\begin{array}{ll}\text { - } & \text { AREA } \\
\text { - } & \text { NPO } \\
\text { - } & \text { CHA } \\
\text { - } & \text { ADA } \\
\text { - } & \text { COAR } \\
\text { - } & \text { IMC } \\
\text { - } & \text { Ibne Sina. }\end{array}$ & $\begin{array}{l}\text { - Local staff } \\
\text { - Local experiences } \\
\text { - Technical staff. } \\
\text { - Machinery and inputs. } \\
\text { - Management capacity }\end{array}$ & $\begin{array}{l}\text { - Agriculture + forestry. } \\
\text { - Health and education. } \\
\text { - Capacity building. } \\
\text { - De-mining } \\
\text { - Planning } \\
\text { - Surveys } \\
\text { - Implementation of projects. } \\
\text { - Monitoring and evaluation. } \\
\text { - Helping returnees to home. } \\
\text { - Motivate afghans (experts / refugees) to } \\
\text { - return back home. } \\
\text { - Shelter provision } \\
\text { - Exesearch } \\
\text { - Income generation } \\
\text { - Adopt strategy } \\
\text { - Planning projects according to strategy. } \\
\text { - Implementation of strategy. }\end{array}$ \\
\hline
\end{tabular}




\section{Strategy Planning}

The information collected in previous steps, that form part of the analytical part of the ZOPP process, was then utilized in the formulation of the "Strategic Plan".

Since the workshop was charged with the responsibility to develop the strategic framework for the Agriculture and Rural Development, a complete planning matrix (PPM) - with indicators and assumptions was not endeavoured.

\section{Overall Goal, Programme Purpose and Results}

In a brain storming session at the end of the day four, participants wrote cards for overall goal and programme purpose. Participants were reminded to recollect the objectives analysis, as it contained the ideas for the goal and purpose. Several ideas were presented by the group, these ranged from increased income and food security to ever higher aims like strong economy and developed country, or some too specific, which were later utilised for the formulation of results.

Through facilitated discussions on several options the workshop participants agreed on the following overall goal and purpose:

\section{SOCIO-ECONOMIC DEVELOPMENT OF COMMUNITIES STIMULATED}

The agreed upon programme purpose highlights the understanding reached while debating the "role of state" at the start of the workshop. The following purpose emphasizes the improved sector management role of the ministries:

\section{RESOURCES AND SUPPORT SYSTEMS FOR IMPROVED PRODUCTION DEVELOPED AND MOBILIZED}

Later, owing to moderated discussions, the group improved the statements of the major objectives (objectives tree) to arrive at following five results:

1) Efficient utilization of the agricultural potential and capacities improved.

2) Water resources and irrigation systems developed and sustainably managed

3) Communities empowered and mobilized (for development)

4) Development (encouragement) of Private Sector, esp. for service provision.

5) Institutions, manpower and resources build up / strengthened

\section{Major Activities}

The last day of the workshop started with the re-cap of the objectives and then the task of activity formulation for all the results was executed by sub-groups. For this purpose, the groups pulled out the key elements from the objectives tree, roles defines in stakeholder analysis and role of state, also, during the exercise, analogous elements were combined in comprehensive activities.

Later, the results of the group work were reviewed jointly by the workshop participants. During this review activities which in the participant's opinion were expedient for the achievement of the result were added.

The next five pages present the strategic plan prepared by the workshop participants. 


\title{
United Nations - Food \& Agricultural Organization, Afghanistan \\ STRATEGIC PLAN
}

\section{FOR AGRICULTURAL \& RURAL DEVELOPMENT MINISTRY LEVEL WORKSHOP}

\author{
Summary of Objectives \& Activities \\ Overall Goal SOCIO-ECONOMIC DEVELOPMENT OF \\ COMMUNITIES STIMULATED.
}

Programme Purpose RESOURCES AND SUPPORT SYSTEMS FOR IMPROVED PRODUCTION DEVELOPED AND MOBILIZED.

\section{$\underline{\text { Result } 1}$ \\ EFFICIENT UTILIZATION OF AGRICULTURAL POTENTIAL AND CAPACITIES IMPROVED.}

\section{Major Activities}

1.1 Update and implement Govt. policies, laws and regulations for:

1.1.1 Support (resolve) land tenure issues.

1.1.2 Improvement and development of land arrangement affairs (fragmentation).

1.1.3 Update and implement forest laws.

1.1.4 Zonation of agriculture crops (classification of zone for specific crops per land characteristics).

1.1.5 Application of (updated) quarantine laws (and establishment of quarantine facilities).

1.2 Improvement of marketing system - support/facilitation and establishment of training institutions.

1.2.1 Construction and rehabilitation of marketing structures.

1.2.2 Provision (improvement) of proper transportation facilities for inputs and produce.

1.2.3 Farm to market road construction

1.2.4 Establishment and activation of agriculture cooperatives.

1.3 Improve and strengthen the (sector) management and systems.

1.3.1 Capacity building of staff.

1.3.2 Improvement of Data and information management and utilization.

1.3.3 Stakeholder coordination and taxation (for uniform / equal interventions country-wide).

1.3.4 Establishment of quality control council.

1.3.5 Networking (telecommunication)

1.4 Development of Extension education program (material and mechanisms)

1.4.1 Awareness programs on agriculture, livestock, forests, etc. for farmers and public.

1.4.2 Use of audio - visual services.

1.4.3 Non formal education

1.5 Promote and facilitate private sector participation (investments) in agriculture sector.

1.5.1 Encourage private sector-for land-to investment

1.6 Provision of Credit facilities / establish system.

1.6.1 Activate Agriculture Development Bank.

1.7 Carry out, promote and facilitate research for improved production.

1.7.I Germ plasm conservation.

1.7.2 Development and improvement of production and multiplication of seeds.

1.7.3 Finding drought resistant varieties of crops. 


\section{United Nations - Food \& Agricultural Organization, Afghanistan STRATEGIC PLAN \\ FOR AGRICULTURAL \& RURAL DEVELOPMENT MINISTRY LEVEL WORKSHOP}

1.7.4 Produce and promote improved (alternäive) cash crops - alternative to poppy.

1.7.J Establishment of laboratories (for agricultural, veterinary/livestock, land/soil, etc) analysis.

1.7.0 Improved breeding \& multiplication of livestock.

1.8 Improvement of plant protection program.

1.9 Fund raising and proposals formulation and submission and follow-up.

$\underline{\text { Result } 2}$

WATER RESOURCE AND IRRIGATION SYSTEMS DEVELOPED AND SUSTAINABLY MANAGED.

\section{Major Activities}

2.1 Improvement and development of water laws, regulation and implementation of policy.

2.2 Develop a water quality policy and a mechanism for the implementation.

2.3 Need assessment for gathering information.

2.3.1 Survey and research of water resources.

2.4 Capacity building of technical staff and communities.

2.5 Introduction of modern irrigation technology.

2.6 Strengthened water user community for participation and increasing (water use) awareness.

2.7 Integrated water management in river basin authorities.

2.7.1 Establishment of river basin authority for water management in Afghanistan.

2.8 Improved and sustainable watershed management.

2.9 Establishment and implementation of water revenue system.

2.10 Rehabilitation of infrastructures.

2.10.1 Update and preparation of master plan (for rehab + construction)

2.11 Rehabilitation of traditional irrigation schemes.

2.11.1 Lining of canals, equitable and optimal use of water. - Vegetation cover protected/ enhanced.

2.12 Rehabilitation and establishment of hydro-meteorological stations.

2.13 Improvement of drainage system.

2.14 Construction of reservoir dams.

2.15 Increasing (establishment of new/additional) irrigation infrastructure.

2.16 Land levelling performed

2.17 Ensure provision of required water quantities as per zones.

2.17.1 Survey for determination of crop water requirement jointly with MAAH (zonation).

2.18 Establishment of National Water Committee for better coordination.

2.19 Proposal preparation and submitting to donors.

2.20 Follow up of proposals with donors. 


\section{United Nations - Food \& Agricultural Organization, Afghanistan \\ STRATEGIC PLAN \\ FOR AGRICULTURAL \& RURAL DEVELOPMENT MINISTRY LEVEL WORKSHOP}

\section{Result 3}

\section{COMMUNITIES MOBILIZED AND EMPOWERED (FOR DEVELOPMENT).}

\section{Major Activities}

3.1 Need assessment of livelihood and for development (of rural areas).

3.2 Community organization.

3.2.1 Establishing the community centres.

3.2.2 Establishment joint management team with donors and implementers.

3.2.3 Better organization (A/M organizations).

3.2.4 Promote good behaviour among the people (facilitate in review of customs and traditions)

3.2.5 Promote and facilitate in community participation in development (social movement).

3.3 Establishment of a program for capacity building of communities - for self-help and collective working in social, technical and management aspects.

3.3.1 Establishment of Training centres.

3.3.2 Conduct (organize) rural literacy courses in coordination with Ministry of Education.

3.3.3 Provide equipment and tools for training, education (capacity building).

3.4 Enhance Income generation prospects.

3.4.1 Identify income generation and livelihood opportunities, facilitate utilization.

3.4.2 Establishment of vocational training centres, and provide skills training.

3.4.3 Establishment of Micro finance and credit system.

3.4.4 Handicraft and artisan production development.

3.4.5 Introducing diversified crops in agriculture.

3.4.6 Improved seed and fertilizer distribution - through micro enterprises.

3.5 Promote Women's involvement on socio economic sides.

3.5.1 Train and provide small businesses for women.

3.6 Rehabilitate and develop Infrastructures.

3.6.1 Useful planning for infrastructure and projects for rural areas.

3.6.2 Prioritization of projects.

3.6.3 Promote community participation and ownership of the projects.

3.6.4 Providing basic services / facilities such as drinking water, clinics, sanitation, environment, hygiene, etc.

3.6.4.1 Coordination and networking with other ministries.

3.6.5 Improvement of roads from villages to markets.

3.6.6 Improving communication facilities.

3.7 Develop and implement Awareness programs.

3.7.1 Aware the community about the basic human rights, women rights, family planning, etc.

3.7.2 Facilitate and support in Family planning.

3.7.3 Use of media facilities and public gathering (e.g. mosques) for awareness.

3.8 Improve management (at MRRD).

3.8.1 Introduce and facilitate in adopting to modern techniques in resource management.

3.8.2 Provide resource management facilities / trainings.

3.8.3 Promote adequate usage of resources (planning, $M+E$, etc.)

3.8.4 Institute close coordination with Ministry of Internal Affairs and other related organization for the security of communities and services / interventions.

3.9 Proposal writing for rural rehabilitation and development projects.

3.10 Follow-up of proposals. 


\section{United Nations - Food \& Agricultural Organization, Afghanistan STRATEGIC PLAN \\ FOR AGRICULTURAL \& RURAL DEVELOPMENT MINISTRY LEVEL WORKSHOP}

\section{Result 4}

DEVELOPMENT (ENCOURAGEMENT) OF PRIVATE SECTOR, ESP. FOR SERVICE PROVISION.

\section{Major Activities}

4.1 Encourage and facilitate private sector in service provision and infrastructure rehabilitation/development.

4.1.1 Sensitize Govt. (public sector) and enhance awareness about potential and role of private sector (in service provision).

4.1.2 Discuss and develop roles and scope for private sector (in service provision).

4.2 Create conducive environment for private sector participation in development.

4.2.1 Update policies and propagate.

4.2.2 Provide constitutional (guarantees for investment protection / protection of local industries) and rules \& regulations it.

4.2.3 Improvement of communication and transport facilities

4.2.4 Improvement of Security

4.2.5 Enhance confidence on banking system.

4.2.6 Understanding of time...??

4.2.7 Relation with Govt. and Donors...??

4.3 Identify gaps in service provision and sensitize government and private sector.

4.3.1 Regularly collect information / data on efficiecncy (outreach) of government services, analyse and share/disseminate widely.

4.4 Prepare feasibilities (info packages) of projects/venture and distribute among existing and potential private sector investors. .

4.4.1 Identify services / production / infrastructure projects (schemes) for private sector on BOT basis (build, operate and transfer).

4.5 Increase availability of professional / technical staff (for private sector).

4.5.1 Encourage return of trained / experienced Afghans.

4.5.2 Training for personnel.

4.6 Organize awareness and training events for private sector.

4.6.1 Improve the role of private sector in international trade (WTO)

4.6.2 Linkage and coordination with other industries

4.6.3 Support of media

4.7 Marketing

4.7.1 Need assessment for marketing

4.7.2 Propagation for marketing

4.7.3 lligh quality processing, sorting, packaging, of material. 


\section{United Nations - Food \& Agricultural Organization, Afghanistan \\ STRATEGIC PLAN \\ FOR AGRICULTURAL \& RURAL DEVELOPMENT MINISTRY LEVEL WORKSHOP}

\section{Result 5}

INSTITUTIONS, MANPOWER AND RESOURCES BUILD UP / STRENGTHENED.

\section{Major Activities}

5.1 Review of old rules and regulations.

5.2 Recruitment of skilled staff.

5.2.1 Appointment on merit.

5.3 Provision of needed equipment and machineries for institutions.

5.4 Providing / establishment of financial base for proper running of institutions.

5.4.1 Optimization (efficient use) of resource and potential.

5.5 Develop and implement scientific management systems, awareness and train staff.

5.5.1 Transparency and accountability (admin and finance).

5.5.2 Creating a system to monitor and control institutions.

5.5.3 Improving reporting system

5.6 Enhance the capacities of the staff - for better working and management.

5.6.1 Training needs assessment/

5.6.2 Providing ground for in service (training) of staff.

5.6.3 Improvement of women's capacities in the institutions.

5.7 Improve personnel management and working of staff.

5.7.1 Encouraging the skilled and efficient ones and punishment of corrupts.

5.7.2 Increasing the wages and salaries.

5.7.3 Increase awareness about work ethics. 


\section{Workshop Evaluation}

The last card writing exercise was the evaluation of workshop. Participants were asked to evaluate the workshop by giving their comments on cards about:

1) What was not good in the workshop and could be avoided next time,

2) What did they like a out the workshop?

Critical comments were concerning the shortage of time cornpared to workload, inconsistent participation by some, absence of public address (PA) system, weak selection of participants, weakness of translation and inadequate venue.

In spite of this, vast majority of the participants expressed appreciation for the methodology ZOPP, group work; and professional facilitation; and, articulated their pleasure with the outcome of the workshop and personal learning achievements. They also appreciated the organisational arrangements and offered their sincere thanks for FAO.

Feedback given by the workshop participants is presented on the following pages.

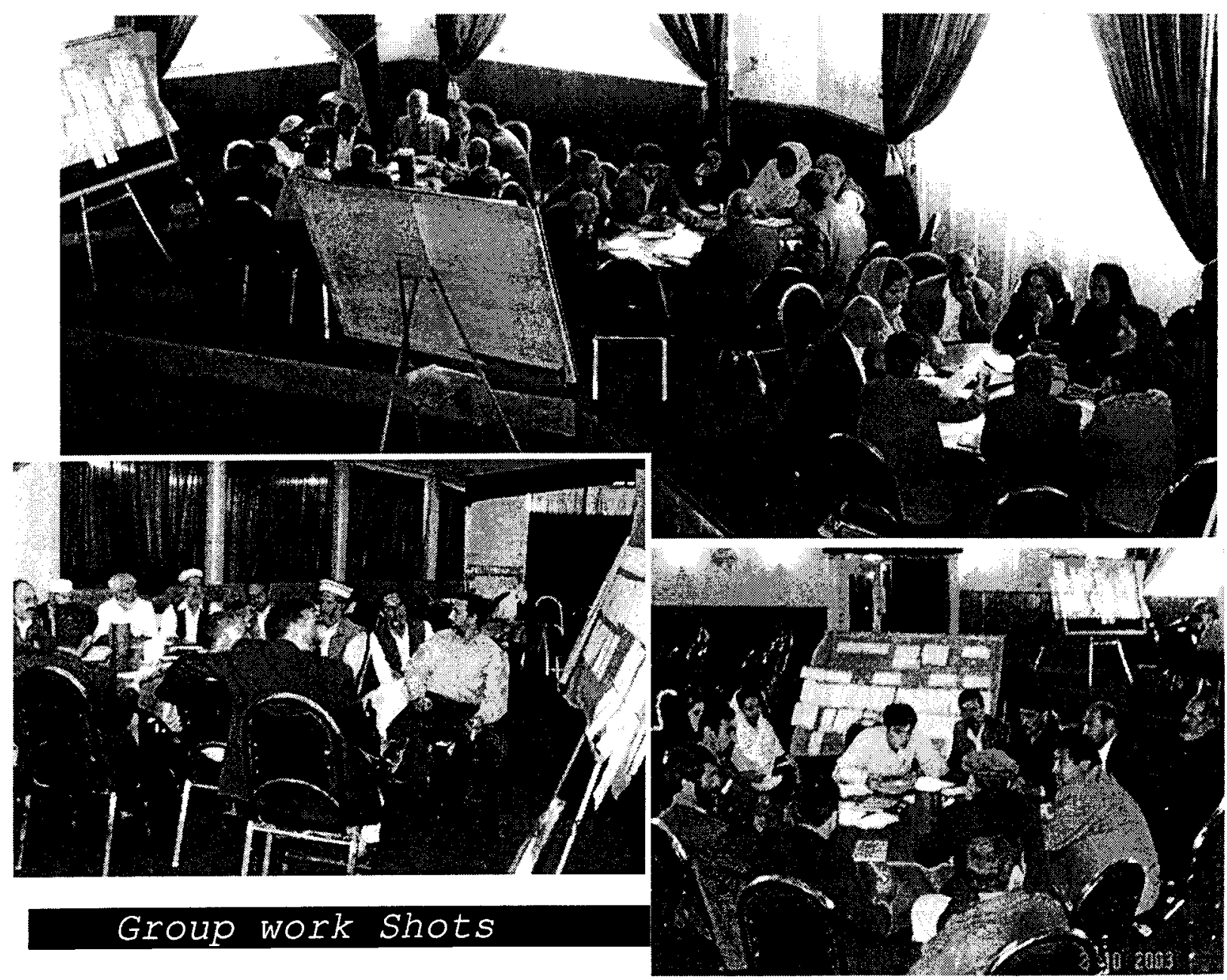




\section{United Nations - Food \& Agricultural Organization, Afghanistan \\ EVALUATION OF THE WORKSHOP \\ FOR AGRICULTURAL \& RURAL DEVELOPMENT MINISTRY LEVEL WORKSHOP}

\section{Critical Remarks}

- No loudspeakers (PA system).

- Big issues... short time.

- Some participants did not follow the workshop rules.

- Participants were irregular and they were not able to link the issues. These people asked unrelated questions and wasted time of others.

- Time was short.

- Time is less ... programme (agenda) wide.

- Time was short.

- Loudspeaker was not available.

- Little time for group work.

- Only time was little.

- Weak translation.

- Less debate

- Weak time management.

- Except Engr. Rahim, the other translators were not good.

- Food was good but (sitting) arrangement not.

- Only the time was not enough.

- Large volume of work compared to available time.

- Time was very short, place was improper.

- Time was short, place was not good - was too noisy.

- Time was short against the task.

- Time was short for practical tasks.

- Translators some time were unable to translate on the basis of presentations.

- Time was not enough.

- Hall was not comfortable (kitchen noises), Food \& tea was not on proper time, and, speaker (mic) was needed especially for presentations.

- Only time was short

- Time was short; copy of report should be given to the participants.

- There was noise from outside (traffic) and hall staff (kitchen). Parking was not good.

- Loudspeaker and mic were not there, we had difficulty hearing each other.

- Time was very short and problem of English.

- There was no mic

- The after lunch tea was cold and most of the participants were not coming on time.

- Dear Mahmood (facilitator), the final day of the workshop was a little confused for every participant, because your translator couldn't explain your idea, in next workshop you should keep best translator. 


\section{United Nations - Food \& Agricultural Organization, Afghanistan EVALUATION OF THE WORKSHOP FOR AGRICULTURAL \& RURAL DEVELOPMENT MINISTRY LEVEL WORKSHOP}

- 1) Large number of participants; 2) Some people were coming only for lunch; 3) The participants capacities were different; 4) time was long for high level people; 5) Females were less.

- Background as an example and achievement and achievement somewhere else.

- Time was not enough.

\section{Complimentary Remarks}

- It was beneficial personally for me. FAO really planned a good workshop. It was learning (new) method for me.

- Was good, systematic, and comprehensive.

- Teacher (facilitator) was good; system was good; participants were active; food was good; group work was good; Hope to be repeated.

- Methodology was good; I learned many things.

- Thanks to FAO and facilitator; the method was good; Food and tea were good as well.

- It was so good, that its money (worth) can not be counted. The method was very good.

- The contents of workshop were relevant to community needs. The teaching method was excellent. Everybody participated in workshop. I hope you organize such other workshops.

- The workshop was conduct in good fashion and method was very good.

- Good luck Mr. Mahmood - the workshop in all context was good, because that was the first time I participated in such workshop.

- It was a new and good method; such method was first time used here.

- Very professional people carried out the workshop.

- The workshop was very professionally conducted for development of sectors of agriculture, irrigation and rural development. The place was proper and food was good.

- Group work - good; women participation - good; teaching method - good.

- The workshop really reflected the national level problems and found proper solutions.

- Workshop was very useful and learning. But, the duration was short.

- I thank you for participation (facilitation) and holding this workshop.

- Good behaviour of the facilitator; Good translation of Engr. Rahim; Proper place for conducting the workshop.

- Thanks to Mr. Mahmood and Engr. Rahim. Materials were enough; I succeeded to gain very high benefit in these 5 days of workshop.

- It's a good system for raising capacities. It is the best method.

- It was learning experience and was good for daily work of the ministries. It is good for our future works.

- The workshop was interesting and learning. 


\section{United Nations - Food \& Agricultural Organization, Afghanistan EVALUATION OF THE WORKSHOP FOR AGRICULTURAL \& RURAL DEVELOPMENT MINISTRY LEVEL WORKSHOP}

- The workshop was interesting and it was learning experience for me.

- Thanks to Mr. Mahmood, Engr. Rahim and others.

- Method was good. Behaviour of the facilitator was good. Food was good.

- It was good workshop. The facilitator was very successful.

- It was excellent workshop; I expect such workshop on Veterinary as well:

- Very good method, thank you.

- Conducting of such workshop by FAO was really good.

- The workshop was fruitful - actually the workshop was implemented in participatory manner.

- Method was good.

- Group discussions, presentations and question \& answer sessions were good. Facilitation good.

- Thanks to the facilitators, the workshop was really good. Wish him - the facilitator, success. Thanks.

- The workshop was interesting. Methodology used was good. Facilitators were also good.

- It was really good workshop. We learnt many things. Thanks to Engr. Rahim and Mr. Mahmood.

- Regards to FAO staff, it was good, we expect such workshops in the future.

- I confirm the work was carried out. Methodology was good. Food and place was good.

- The contents were very much beneficial.

- The contents of this workshop was very good, especially facilitator.

- The workshop was very very good and I am glad at all. Thank you.

- Methodology was good and we succeeded to make a plan.

- Method was good. Good understanding between the participants was reached.

- The methodology used was good and it was learning as well.

- It was an excellent step for planning.

- It was very useful for us.

- The method used was good. Strategy was developed with care.

- The workshop was really learning, such workshops support capacity building.

- Very useful.

- Yes it was very useful for our future planning and action.

- The method was very good. The workshop was very interesting and very useful for me.

- I like good management in my country and security and proper planning.

- I learned new things, all participants fully participated. Time short, but maximum benefits were drawn. 


\section{Workshop Evaluation \& Adjournment}

Ms. Noorzia Kohistani, Director of Capacity Building, MRRD closing the workshop extended earnest gratitude on behalf of MRRD to the facilitator and FAO for organizing and excellent workshop. She expressed complete satisfaction over the process and the results of the workshop and congratulated the participants for the successful accomplishment of the task. She

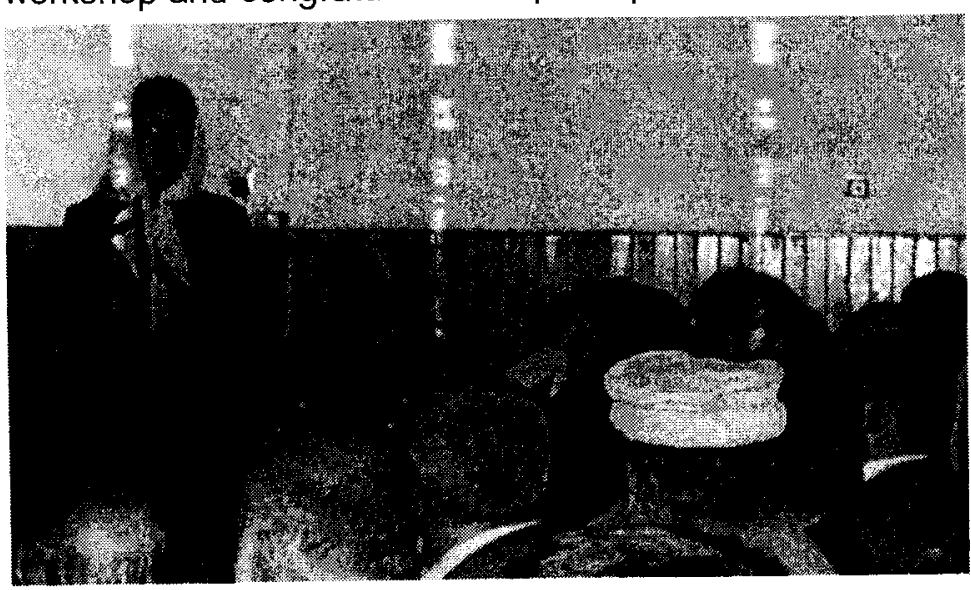
stated that the workshop has set the benchmark for all subsequent such events and hoped that more such workshops for planning of other matters / topics would be organized. Ms. Kohistani lauded the methodology and stated that all the participants are extremely delighted over the learning gains achieved in such a short time. Finally, she once again thanked the facilitator and Engr. Rahim, SNPO FAO for excellent conduct and organization respectively.

Sharing the sentiments of the workshop participants, Mr. Mannan stated that the difference between the previous and this strategy is that earlier foreigners used to prepare it while this one is prepared by the Afghans themselves. Previously, the strategies were bulky documents hardly ever read in full and when shared only $20 \%$ of the contents were remembered whereas this time $90 \%$ has already been learnt by heart because we did it ourselves. This is our strategy and we will make all efforts to realize it. Therefore, we request the aid community that this strategy should be implemented.

Mr. Mannan then, on behalf of all the participants, thanked the facilitator for effective guidance provided through out the workshop and teaching the intricacies of not only strategic planning but also for educating the group about the technical / sectoral insights. In the end he thanked FAO for the selection of the facilitator and professional organization of the workshop.

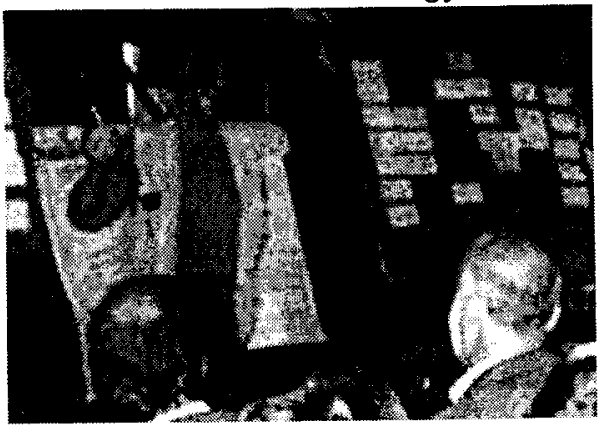

Later, the participants were awarded certificates of attendance by the Director (CB), facilitator, Egnr Rahim, SNPO FAO and other senior staffs from the three participating ministries.
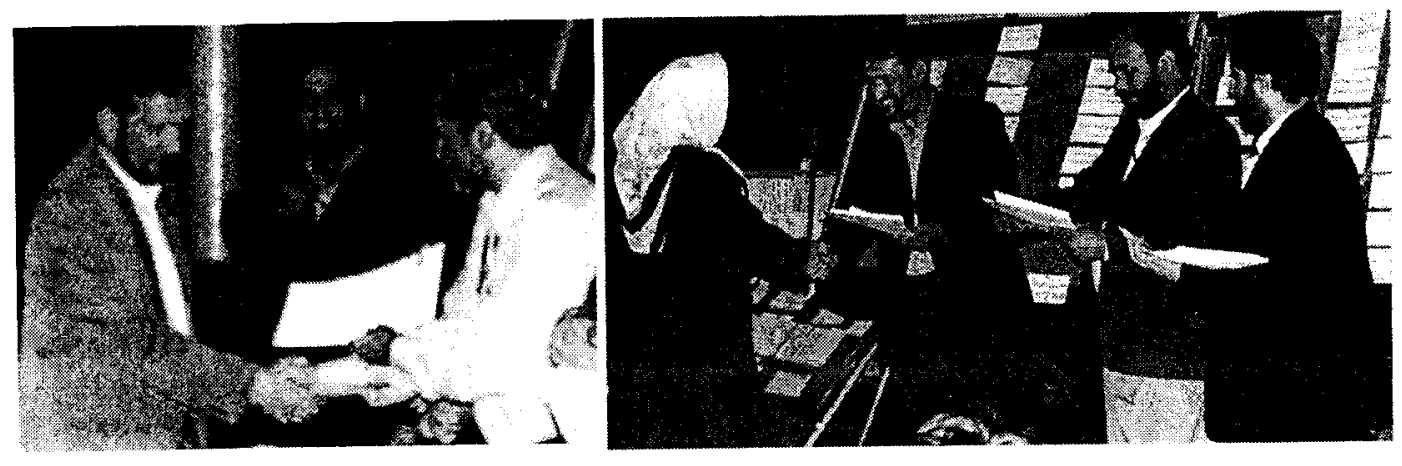

The workshop was then adjourned with vote of thanks and good wishes for the implementation of the plan prepared. 


\begin{tabular}{|c|c|c|c|}
\hline No & Name & Title & Ministry / Agency \\
\hline 1 & Abdul Hadi & Director of Planning & MAAH \\
\hline 2 & Besmillah & Duty Presenting & MAAH \\
\hline 3 & Abdul Wasi & General Promotion president & MAAH \\
\hline 4 & Abdul Saboor & Director of Planning of Agriculture & MAAH \\
\hline 5 & Ghulam Rabani & Deputy Director & MAAH \\
\hline 6 & Abdul Ghafoor & Libratory Director\& plant protection & MAAH \\
\hline 7 & Ghulam Yahya & General Secretary of Kabul & MAAH \\
\hline 8 & Dust Muhammd & General Promotion \& planning & MAAH \\
\hline 9 & Zar Gul & Monitoring & AREA (NGO) \\
\hline 10 & Muhammd Junid & Agriculture & ACTED (NGO) \\
\hline 11 & Farida & NSP Information & MAAH \\
\hline 12 & Najiha & Director of Country Department & MRRD \\
\hline 13 & Eng. M. Asif & Contract Counter & MRRD \\
\hline 14 & Abdul Rahim Zarim & Director Maida & MRRD \\
\hline 15 & Bashir Khan & Admin Director & MRRD \\
\hline 16 & Eng. Zalmi & Director of Control & MRRD \\
\hline 17 & Abdulmubin & Parchment & MRRD \\
\hline 18 & Eng. M. Seediq & Director of Social & MRRD \\
\hline 19 & Haress & Secretary & OXFAM (NGO) \\
\hline 20 & Abdul Samaad & Joiner Deputy Planning & MIWRE \\
\hline 21 & M. Rahim & General Promotion Cultivation President & MIWRE \\
\hline 22 & Eng. Sultan Muhmood & General Director of Irrigation & MIWRE \\
\hline 23 & Gul Bahram & General President of Irrigation & MIWRE \\
\hline 24 & Eng. M. Nadir & Director of Technical\& Construction & MIWRE \\
\hline 25 & Khalil Rahman & Construction Engineer & MIWRE \\
\hline 26 & Abdulrahman Manan & Assist Manager & ICARDA \\
\hline 27 & Alaam shah & Director Rural Development & MRRD \\
\hline 28 & Yaar Muhammad & Director of Education & MIWRE \\
\hline 29 & Zeenatullah & Extensionist & SCA \\
\hline 30 & Abdul Basir & General Planning President & MAAH \\
\hline 31 & Shahperi & Gender Policy Section Head & MRRD \\
\hline 32 & Amina & Contract President & MRRD \\
\hline 33 & M. Saalim & Personnel Assistant & MRRD \\
\hline 34 & Sayed Abdul Khaliq & General Panning President & MRRD \\
\hline
\end{tabular}


$28^{\text {th }}$ September $-2^{\text {nd }}$ October 2003, Kabul

\begin{tabular}{|c|c|c|c|}
\hline No & Name & Title & Ministry / Agency \\
\hline 35 & Shamsuddin & Planning & MRRD \\
\hline 36 & Abdulmutalib & Agriculturalist & ISRA \\
\hline 37 & Momeen Kakar & General Section Agriculture & MAAH \\
\hline 38 & M. Tahoos & General Planning President & MRRD \\
\hline 39 & Nasir Ahmad & Joiner Deputy Section & $\mathrm{CHA}$ \\
\hline 40 & Mir Zafaruddin & Contract Assistant Manager & MRRD \\
\hline 41 & Razia & Contract Assistant & MRRD \\
\hline 42 & Hassina & Contacts Engineer & MRRD \\
\hline 43 & Eng. Abdul Wasi & Plant Protection & MAAH \\
\hline 44 & Dr. Durbin Sayaaf & Veterinary & MAAH \\
\hline 45 & Niaaz Muhammad & QDS President & MAAH \\
\hline 46 & Fouzia & Assistant Pogramme & MRRD \\
\hline 47 & Najiullah & Management Manager & MRRD \\
\hline 48 & Noor Zia Kohistani & Director of Capacity Building & MRRD \\
\hline 49 & Safeea Sideeqi & Gender Advisor & MRRD \\
\hline 50 & Abdul Ghafar & Director of Management & MRRD \\
\hline 51 & Eng. M. Hanif & Director Emergency & MRRD \\
\hline 52 & Amamuddin & Secretarial & MRRD \\
\hline 53 & Ahmad Fahim & Emergency/ Disaster & MRRD \\
\hline 54 & Abdul Wali & Emergency/ Disaster & MRRD \\
\hline 55 & Ahmad Fahim & Irrigation Office & MRRD \\
\hline 56 & Ahmad Shafeeq & Agriculturist & NPO \\
\hline 57 & M. Musa Shrifi & Director of Planning & MRRD \\
\hline 58 & Eng. Hayat Llah & Deputy Director Irrigation & MRRD \\
\hline 59 & Muhammad Rasul & Director of Social Protection & MRRD \\
\hline
\end{tabular}

